\title{
Air Quality and Industrial Emissions in the Cities of Kazakhstan
}

\author{
Daulet Assanov $^{1}$ (D), Valeryi Zapasnyi ${ }^{2}$ and Aiymgul Kerimray ${ }^{3, *(D)}$ \\ 1 Excellence Center Veritas, D. Serikbayev East Kazakhstan Technical University, \\ Ust-Kamenogorsk 070003, Kazakhstan; dasanov@ektu.kz \\ 2 The School of Earth and Environmental Sciences, D. Serikbayev East Kazakhstan Technical University, \\ Ust-Kamenogorsk 070003, Kazakhstan; Vzapasny@ektu.kz \\ 3 Center of Physical-Chemical Methods of Research and Analysis, Al Farabi Kazakh National University, \\ Almaty 050012, Kazakhstan \\ * Correspondence: aiymgul.kerimray@cfhma.kz
}

Citation: Assanov, D.; Zapasnyi, V.; Kerimray, A. Air Quality and

Industrial Emissions in the Cities of Kazakhstan. Atmosphere 2021, 12, 314. https://doi.org/10.3390/

atmos12030314

Academic Editor:

Liudmila Golobokova

Received: 18 January 2021

Accepted: 22 February 2021

Published: 28 February 2021

Publisher's Note: MDPI stays neutral with regard to jurisdictional claims in published maps and institutional affiliations.

Copyright: (c) 2021 by the authors. Licensee MDPI, Basel, Switzerland. This article is an open access article distributed under the terms and conditions of the Creative Commons Attribution (CC BY) license (https:/ / creativecommons.org/licenses/by/ $4.0 /)$.

\begin{abstract}
Industrial emissions are of major concern, especially in developing countries. Hence, there is a need for studies that investigate the trends in industrial emissions in these countries. The purpose of this study is to discuss trends in industrial emissions in Kazakhstan and the air pollution level in its industrial cities. Data on emission limit values from the permitting documents of twenty-one power plants and nine metallurgical enterprises of Kazakhstan were analyzed. Eight cities (out of fourteen) had a "high" level of atmospheric air pollution according to the Air Pollution Index in 2019. Most of the considered enterprises increased their emission limit values compared to the previous permitting period. In some cities there is a lack of monitoring stations, indicating the need for improving the spatial coverage of the air quality monitoring network in the industrial cities of Kazakhstan. The location of industrial plants far outside the cities could reduce the exposure of the urban population to air pollution. Kazakhstan urgently needs to adopt stringent emissions standards for coal-fired power plants and heavy industrial plants. The national air quality standards and definitions of air pollutants need to be updated based on the latest scientific knowledge.
\end{abstract}

Keywords: Kazakhstan; industry pollution; environmental policy; air quality

\section{Introduction}

The industry is one of the major sources of air pollution and greenhouse gases (GHG) emissions [1]. Globally, there is an increasing trend of GHG emissions from industry [2]. Industrial GHG emissions have declined in OECD countries but have increased in the Asian region [2]. Geng et al. [2] highlight the need for studies to learn and share experiences for developing countries. Kazakhstan has experienced considerable economic growth in the last two decades, mainly due to the export of fossil fuels and metals, but it has also undergone many years of environmental degradation because of the poor management of its significant natural resources [3]. The carbon intensity of GDP in Kazakhstan (0.6 kg per PPP \$ of GDP in 2016) is two times higher than the world average value $(0.33 \mathrm{~kg}$ per PPP \$ of GDP) and three times higher than that in the European Union $(0.2 \mathrm{~kg}$ per PPP \$ of GDP) [4]. During the time of the USSR, coal-fired power plants were built to meet the needs of heavy industry and due to the presence of coal mines in the northern, central, and eastern regions of Kazakhstan. In Kazakhstan, there were two industrial sectors, namely power generation and metallurgy, which are the major sources of emissions, as they are responsible for 37\% and 30\% of the country's gross industrial emissions, respectively [5].

Industrial plants in Kazakhstan are required to obtain a "permit for emissions" setting emission limit values (ELV) [6]. ELVs are determined with dispersion models based on the prerequisite for achieving "environmental quality standards" at the border of the sanitary protection zone and in nearby residential areas [6]. Such an approach generally leads to less stringent emission limits than ELVs, which are based on internationally defined best available techniques (BAT) for installations (e.g., EU Industrial Emissions Directive) [7]. In 
theory, the Environmental Code provides a general framework for protecting the health of the population and environment. However, in reality, its implementation is prevented by a lack of mechanisms for its implementation, weak environmental quality standards, and a lack of law enforcement and site control. Since the adoption of the Environmental Code in 2007, 75 amendments have been made, but they have failed to create the prerequisites required for emissions reductions [8]. Investment in the protection of atmospheric air decreased by a coefficient of 2.6: from 443 million US dollars in 2013 to 173 million US dollars in 2018 [9,10].

Kazakhstan ranked as 29th in the world's most polluted countries in 2019 [11]. Most cities in Kazakhstan are not included in global air quality rankings due to the lack of monitoring data linked to global databases. The National Air Quality Monitoring System is owned and operated by Kazakhstan official authorities and does not provide data to the IQ Air [11].

In the wintertime, Nur-Sultan city was ranked in the top ten polluted cities of the world, with daily $\mathrm{PM}_{2.5}$ concentration levels ranging between 100-200 $\mu \mathrm{g} \mathrm{m}^{-3}$ on some days [11]. Almaty city has days with daily $\mathrm{PM}_{2.5}$ concentration levels between 100-200 $\mu \mathrm{g}$ $\mathrm{m}^{-3}$, but it has never ranked in the top ten polluted cities of the world, possibly because of the lack of monitoring data. In many areas of Kazakhstan, winters are long and cold, the heating season lasts for more than half a year. A high level of air pollution in the wintertime in Almaty and Nur-Sultan cities could be associated with higher values of coal consumption at combined heat and power plants (CHPs) and coal combustion by households for heating purposes. [12].

In ten out of eleven selected cities of Kazakhstan, annual levels of pollutant concentrations in the air do not meet the annual limit values set by the European Union [13]. The epidemiological studies by Nugmanova et al. [14,15] showed that Kazakhstan has an increased prevalence of chronic obstructive pulmonary disease (COPD) and bronchial asthma compared to Ukraine and Azerbaijan, which could be associated with poor air quality in Kazakhstan.

Many countries achieved substantial reductions in air pollution levels due to a range of policies and measures. There were substantial declines in $\mathrm{SO}_{2}$ emissions observed in the US [16], Europe [17], and China [18-20] because of stricter environmental regulations, technology improvements, and switching to clean fuel. In large parts of Europe, $\mathrm{SO}_{2}$ concentrations were very low [21]. Many areas in Kazakhstan continue to suffer from high air pollution levels due to weak environmental regulations for the metallurgical industry and coal power plants. There is no appropriate emissions control technology applied locally.

Some studies provide ex-post evaluations of policies to determine whether specific interventions were justified and achieved their objectives. Enrique Conti et al. [22] analyze the current situation of industrial emissions in Europe and discuss the problems associated with Industrial Emissions Directive. Tang et al. [23] provide an ex-post evaluation of the ultra-low emissions standards policy in China by analyzing unit-level data. Newell and Henry [24] assess the environmental legislation, government regulatory institutions, and civil society in the Russian Federation. Cherp et al. [25] evaluate environmental assessment systems of the countries in transition. Most of these studies were conducted in countries with progressive environmental policies. However, a limited number of research studies have been done with a focus on industrial emissions in the Central Asian region and Kazakhstan to date.

Air quality levels in the cities of Kazakhstan have been widely discussed in media reports; however, peer-reviewed studies remain scarce. Previous studies focused on the assessment of air quality mainly in cities of Kazakhstan such as Almaty [26,27] and Nur-Sultan [12,27]. The atmosphere of large cities in Kazakhstan is polluted not only by nitrogen oxides, sulfur, and dust, but also by Volatile Organic Compounds (VOCs). VOC measurements in the atmosphere of Almaty [26] show that the concentration of benzene is $53 \mu \mathrm{g} \mathrm{m}^{-3}$, toluene is $57 \mathrm{\mu g} \mathrm{m}^{-3}$, and ethylbenzene is $11 \mu \mathrm{g} \mathrm{m}^{-3}$. A comparative analysis 
with 19 other large cities showed that Almaty ranks 8th in terms of benzene, toluene, ethylbenzene and xylene (BTEX) pollution. Kerimray et al. [27] analyzed the effect of COVID-19 lockdown restriction measures on the concentration of atmospheric pollutants. During the COVID-19 lockdown period, the concentration of $\mathrm{PM}_{2.5}$ decreased by $21 \%$, $\mathrm{CO}$ and $\mathrm{NO}_{2}$ by $49 \%$ and $35 \%$, respectively, in comparison with $2018-2019$. The study by Ormanova et al. [12] established the influence of the anticyclone on the formation of smog over Nur-Sultan in 2017. In the period from 2006 to 2016, the average annual concentration of pollutants in Nur-Sultan exceeded the average annual WHO standards for $\mathrm{NO}_{2}$ by 1.5-2 times. The average annual concentration of $\mathrm{PM}_{10}$ during the period from 2014 to 2016 increased from 20 to $100 \mathrm{\mu g} \mathrm{m}^{-3}$ [28]. Darynova et al. [29] analyzed $\mathrm{SO}_{2}$ and $\mathrm{HCHO}$ from satellite observations over five cities of Kazakhstan for the period from 2005 to 2016. The highest $\mathrm{SO}_{2}$ pollution was found over Ekibastuz, where the largest two coal-fired power plants are located.

The health impact of air pollution in cities of Kazakhstan was estimated by the studies of Kenessary et al. [30] and Kerimray et al. [31]. Kenessary et al. [30] assessed the health risk associated with the level of air pollution in twenty-six cities of Kazakhstan. An extremely high risk of chronic effects from exposure to heavy metals has been identified in UstKamenogorsk, Almaty, and Balkhash. There was an increased level of Ba, Mn, Pb, V, Zn in the blood of city residents of Aksu and Ust-Kamenogorsk [31], possibly due to the activities of metallurgical enterprises. Kerimray et al. [32] estimated the death rate from air pollution in the large cities of Kazakhstan. In twenty-one cities of Kazakhstan, 8134 adult deaths associated with $\mathrm{PM}_{2.5}$ occur annually (2015-2017 average). The main causes of deaths were coronary heart disease (4080), stroke (1613), lower respiratory tract infections (662), chronic obstructive pulmonary disease (434), and lung cancer (332). The highest death rates were found in three industrial cities: Zhezkazgan, Temirtau, and Balkhash.

The purpose of this study is fourfold: (i) to analyze the state of atmospheric pollution in the cities of Kazakhstan, (ii) to analyze industrial emissions trends in Kazakhstan, (iii) to establish the links between air pollution and industrial emissions, and (iv) to analyze plant-level data on emissions from the permitting documents of thirty large industrial enterprises (power plants and metallurgical enterprises).

\section{Materials and Methods}

\subsection{Sources of the Air Quality Data}

Annual concentration levels of TSP, $\mathrm{NO}_{2}, \mathrm{SO}_{2}$, and $\mathrm{CO}$ for 2019 were obtained from the information bulletin on the state of the environment of the Republic of Kazakhstan of Kazhydromet, the National Hydrometeorological Service of Kazakhstan [33]. Kazhydromet is the owner and the operator of the National Air Quality Monitoring Network (NAQMN). Kazhydromet publishes information bulletins on a monthly and annual basis.

\subsection{Air Quality Standards and Air Pollution Index (API)}

Annual concentration levels of TSP, $\mathrm{NO}_{2}, \mathrm{SO}_{2}$ have been compared with national and international air quality standards. In Kazakhstan, air quality standards are defined as maximum allowable concentrations (MACs). Levels of MACs were approved in 2015 by the Hygienic Standards for Atmospheric Air in Urban and Rural Settlements [34]. The maximum "one-time" and average daily concentrations and hazard classes for 684 substances have been established (Table 1). There are differences between the air quality standards of Kazakhstan and WHO [35]: the WHO uses daily and annual average limit values for $\mathrm{PM}_{10}$, $\mathrm{PM}_{2.5}$, and $\mathrm{NO}_{2}$ to assess air quality, whereas in Kazakhstan, maximum one-time values are employed, and average annual MACs are not. The maximum one-time MAC for $\mathrm{PM}_{2.5}$ used in Kazakhstan is sixteen times higher than the average annual WHO's standard. 
Table 1. Limit values of the WHO and Kazakhstan for the level of pollutants in the air.

\begin{tabular}{ccccccc}
\hline \multirow{2}{*}{ Pollutant } & \multicolumn{2}{c}{$\begin{array}{c}\text { One-Time MAC, } \\
\mu \mathbf{g ~ m}^{-3}\end{array}$} & \multicolumn{2}{c}{$\begin{array}{c}\text { Average Daily MAC, } \\
\mu \mathbf{g ~ m}^{-3}\end{array}$} & \multicolumn{2}{c}{$\begin{array}{c}\text { Average Annual MAC, } \\
\mu \mathbf{g ~ m}^{-3}\end{array}$} \\
\cline { 2 - 7 } & Kazakhstan & WHO & Kazakhstan & WHO & Kazakhstan & WHO \\
\hline $\mathrm{TSP}$ & 500 & - & 150 & - & - & - \\
$\mathrm{PM}_{10}$ & 300 & - & 60 & 50 & - & 20 \\
$\mathrm{PM}_{2.5}$ & 160 & - & 35 & 25 & - & 10 \\
$\mathrm{SO}_{2}$ & 500 & - & 50 & 20 & - & - \\
$\mathrm{NO}_{2}$ & 200 & - & 40 & - & - & 40 \\
\hline
\end{tabular}

To assess the air pollution level, indices that are related to the MAC values are employed in Kazakhstan. The most important is the Air Pollution Index (API). For its calculation, the average values of the concentrations of various pollutants are divided by their respective MAC and benchmarked by a factor related to the $\mathrm{MAC}$ value of $\mathrm{SO}_{2}$. In this study, API values for the cities of Kazakhstan were obtained from the information bulletin on the state of the environment of the Republic of Kazakhstan for 2019 for the cities of Kazakhstan [33]. The quality in the city is estimated by four classes: Low, Increased, High, Very High (Table 2).

Table 2. Estimation of the air pollution levels by Air Pollution Index (API).

\begin{tabular}{cc}
\hline Pollution Level & Level of API \\
\hline Low & $0-4$ \\
Increased & $5-6$ \\
High & $7-13$ \\
Very high & $>14$ \\
\hline
\end{tabular}

\subsection{Description of Selected Enterprises and Their Permitting Documents}

Permitting documents of industrial enterprises are taken from the reports of the state environmental expertise on the website of electronic licensing of Kazakhstan http:/ / elicense.kz/ (accessed on 23 April 2020). The ELVs (emission limit values) that are reported in the permitting documents of major industrial enterprises in the power and metallurgy sectors are analyzed. We evaluated the efficiency of environmental regulations and changes in recent years by comparing the existing (valid at the time of this study) with the previous (valid in the previous permitting period) ELVs of the major industrial enterprises.

The power plants selected for this study have a total available capacity of $12.9 \mathrm{GW}$, which is $68 \%$ of the total available capacity in the country (18.9 GW) (Appendix A, Table A1). Three major state district power stations called GRES are thermal power plants that produce mainly electricity. Aksu GRES, Ekibastuz GRES-1, and Ekibastuz GRES-2 have the available capacity of $2450 \mathrm{MW}, 4000 \mathrm{MW}$, and $1000 \mathrm{MW}$ respectively, representing 39\% of the total available capacity in the country. The remaining eighteen power plants are combined heat and power plants (CHP), producing not only electricity but also serve as sources of heat in centralized heat supply systems of the respective cities. District heating systems based on coal CHPs are common in most of the cities in Kazakhstan.

All selected power plants use coal as a main source of fuel (except for Almaty CHP-1). In all power plants, coal is flared in the pulverized state; ignition is carried out with fuel oil. In all coal power plants of Kazakhstan (except for one station) emissions control devices for $\mathrm{SO}_{2}$ and $\mathrm{NO}_{2}$ emissions are not employed. In most of the power plants in Kazakhstan, a method for wet cleaning of the flue gas from Russian manufacturers named "emulsifiers" is used to control ash. In the permitting documents of many power plants in Kazakhstan, it is indicated that ash collection is represented by "emulsifiers" with an efficiency of about $99 \%$. However, the collection efficiency of fine dust $\left(\mathrm{PM}_{2.5}\right)$ is not reported. More advanced pollution control devices for PM, such as fabric filters, are not yet employed. 
Information from approved ELVs from coal combustion for selected power plants is presented in Appendix A (Table A1).

Nine metallurgical enterprises produce a major share of the country's total metals output: $65 \%$ of ferroalloys, $100 \%$ of copper, $100 \%$ of iron and steel, $95 \%$ of zinc, $94 \%$ of lead. Information from approved ELVs for selected metallurgical plants is presented in Appendix A (Table A1).

\subsection{Description of the Selected Cities}

The cities selected in this study have major industrial plants: either coal power plants or metallurgical plants. Fourteen cities were selected in this study. The sum of gross emissions from stationary sources of the fourteen cities is 1369 thousand tons, whereas the total national emissions from stationary sources is 2483 thousand tons. Thus, the selected cities represent $55 \%$ of national emissions from stationary sources, while representing only $30 \%$ of the population of the country. Two cities have a population of more than 1 million people (Nur-Sultan and Almaty), five cities between 300 thousand to 500 thousand people, and seven cities have less than 200 thousand people (Table 3).

Table 3. Main characteristics of the selected industrial cities.

\begin{tabular}{|c|c|c|c|c|c|c|c|}
\hline City & $\begin{array}{l}\text { Major Industrial } \\
\text { Plants }\end{array}$ & $\begin{array}{l}\text { Location } \\
\text { of the } \\
\text { Industrial } \\
\text { Plant }\end{array}$ & $\begin{array}{l}\text { Main Fuel } \\
\text { Used by } \\
\text { Power } \\
\text { Plants }\end{array}$ & $\begin{array}{c}\text { Population, } \\
\text { Thousand } \\
\text { People }\end{array}$ & $\begin{array}{c}\text { Number of } \\
\text { Atmospheric Air } \\
\text { Monitoring } \\
\text { Posts }{ }^{1}\end{array}$ & $\begin{array}{l}\text { Number of } \\
\text { Vehicles per } \\
100 \text { Persons }\end{array}$ & $\begin{array}{c}\text { Number of } \\
\text { Transport } \\
\text { Vehicles, } \\
\text { Thousand }^{2}\end{array}$ \\
\hline Nur-Sultan & CHP-1, CHP-2 & In the city & Coal & 1136 & $7(4 m+3 a)$ & 26 & 300 \\
\hline Almaty & $\begin{array}{c}\text { CHP-1, CHP-2, } \\
\text { CHP-3 }\end{array}$ & In the city & Coal/gas & 1917 & $16(5 m+11 a)$ & 27 & 515 \\
\hline $\begin{array}{c}\text { Ust- } \\
\text { Kamenogorsk }\end{array}$ & $\begin{array}{c}\text { Ust-Kamenogorsk } \\
\text { CHP, Sogrinsk } \\
\text { CHP, Kazzinc } \\
\text { Ust-Kamenogorsk } \\
\text { Metallurgical } \\
\text { Complex }\end{array}$ & In the city & Coal & 333 & $7(5 m+2 a)$ & 25 & 83 \\
\hline Ridder & $\begin{array}{l}\text { Kazzinc Ridder } \\
\text { Metallurgical } \\
\text { Complex, CHP }\end{array}$ & In the city & Coal & 47 & $3(2 a+1 a)$ & 25 & 12 \\
\hline Karaganda & CHP-1, CHP-3 & In the city & Coal & 498 & $7(4 m+3 a)$ & 23 & 114 \\
\hline Temirtau & $\begin{array}{l}\text { ArcelorMittal } \\
\text { Temirtau, CHP }\end{array}$ & In the city & Coal & 179 & $4(3 m+1 a)$ & 23 & 41 \\
\hline Balkhash & $\begin{array}{l}\text { Balkhash Copper } \\
\text { Smelter, CHP }\end{array}$ & In the city & Coal & 73 & $4(3 m+1 a)$ & 23 & 17 \\
\hline Zhezkazgan & $\begin{array}{c}\text { Zhezkazgan } \\
\text { Copper Smelter, } \\
\text { CHP }\end{array}$ & In the city & Coal & 87 & $3(2 m+1 a)$ & 23 & 20 \\
\hline Aktobe & $\begin{array}{c}\text { Aktobe Ferroalloys } \\
\text { Plant }\end{array}$ & In the city & Gas & 501 & $6(3 m+3 a)$ & 19 & 95 \\
\hline Pavlodar & $\begin{array}{c}\text { Pavlodar Alumina } \\
\text { Plant, CHP-1, } \\
\text { CHP-2, CHP-3, } \\
\text { KSP Steel }\end{array}$ & In the city & Coal & 333 & $7(2 m+5 a)$ & 24 & 80 \\
\hline Aksu & $\begin{array}{l}\text { Aksu Ferroalloys } \\
\text { Plant, GRES }\end{array}$ & $2 \mathrm{~km}$ & Coal & 41 & $1(1 \mathrm{a})$ & 24 & 10 \\
\hline Ekibastuz & GRES-1, GRES-2 & $15 \mathrm{~km}$ & Coal & 134 & $3(1 m+2 a)$ & 24 & 32 \\
\hline Rudnyi & $\mathrm{CHP}$ & In the city & Coal & 115 & $2(2 a)$ & 23 & 26 \\
\hline Semei & $\begin{array}{l}\mathrm{CHP} \text {, cement } \\
\text { factory }\end{array}$ & In the city & Coal & 324 & $4(2 m+2 a)$ & 25 & 81 \\
\hline
\end{tabular}

${ }^{1} \mathrm{~m}$-manual station, a-automatic station. ${ }^{2}$ Number of transport vehicles by cities was estimated using number of vehicles, per 100 persons. 


\section{Results}

\subsection{Air Quality in the Cities of Kazakhstan}

Eight cities had a "high" level of air pollution according to the Air Pollution Index data (more or equal to seven) in 2019: Nur-Sultan, Karaganda, Temirtau, Aktobe, Balkhash, Ust-Kamenogorsk, Zhezkazgan, Almaty (Figure 1). The two most populous cities of Kazakhstan (Almaty, Nur-Sultan) were highly polluted. Two cities (Pavlodar, Semei) had an "increased" level of air pollution. Only four of selected cities of Kazakhstan had a "low" level of air pollution.
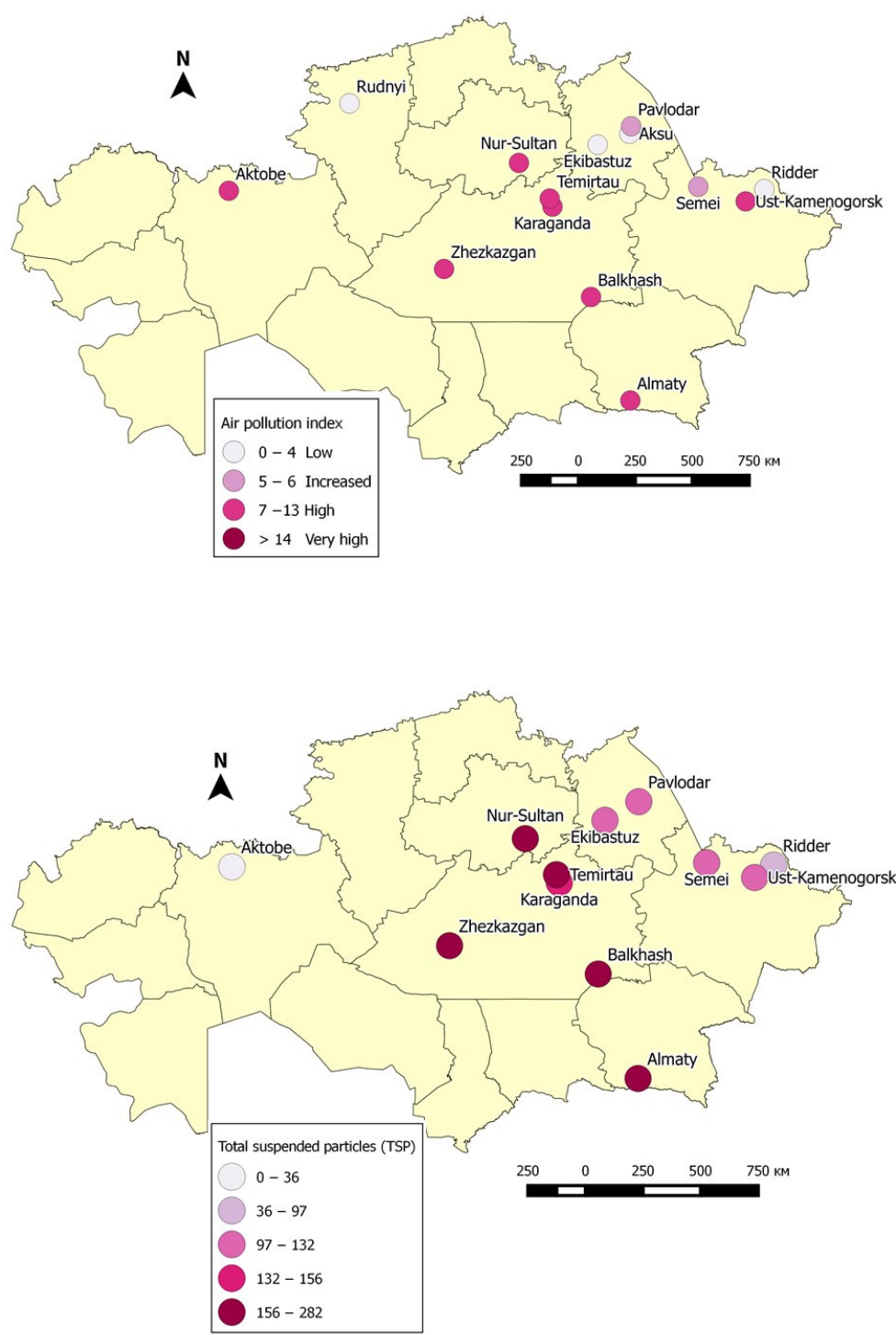

Figure 1. Air pollution index in 2019 (upper map) and average annual concentrations of TSP in the

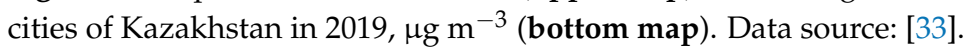

Over the recent years (2015-2019), deterioration in air quality was observed in seven cities (Figure 1). Air quality worsened in large cities: in Almaty the API increased from 7.6 in 2015 to 8 in 2019, in Nur-Sultan from 4.2 to 7. An increase in API was also observed in Temirtau (API increased from 7.9 to 9) and in Zhezkazgan (an increase in the IPA from 7.5 to 8). If a longer period was considered (2009-2019), there is a similar tendency: eight cities had rising API. Consistently rising API in both periods (2009-2019 and 2015-2019) was observed in five cities: Balkhash, Pavlodar, Nur-Sultan, Zhezkazgan, Temirtau (Figure 2). 


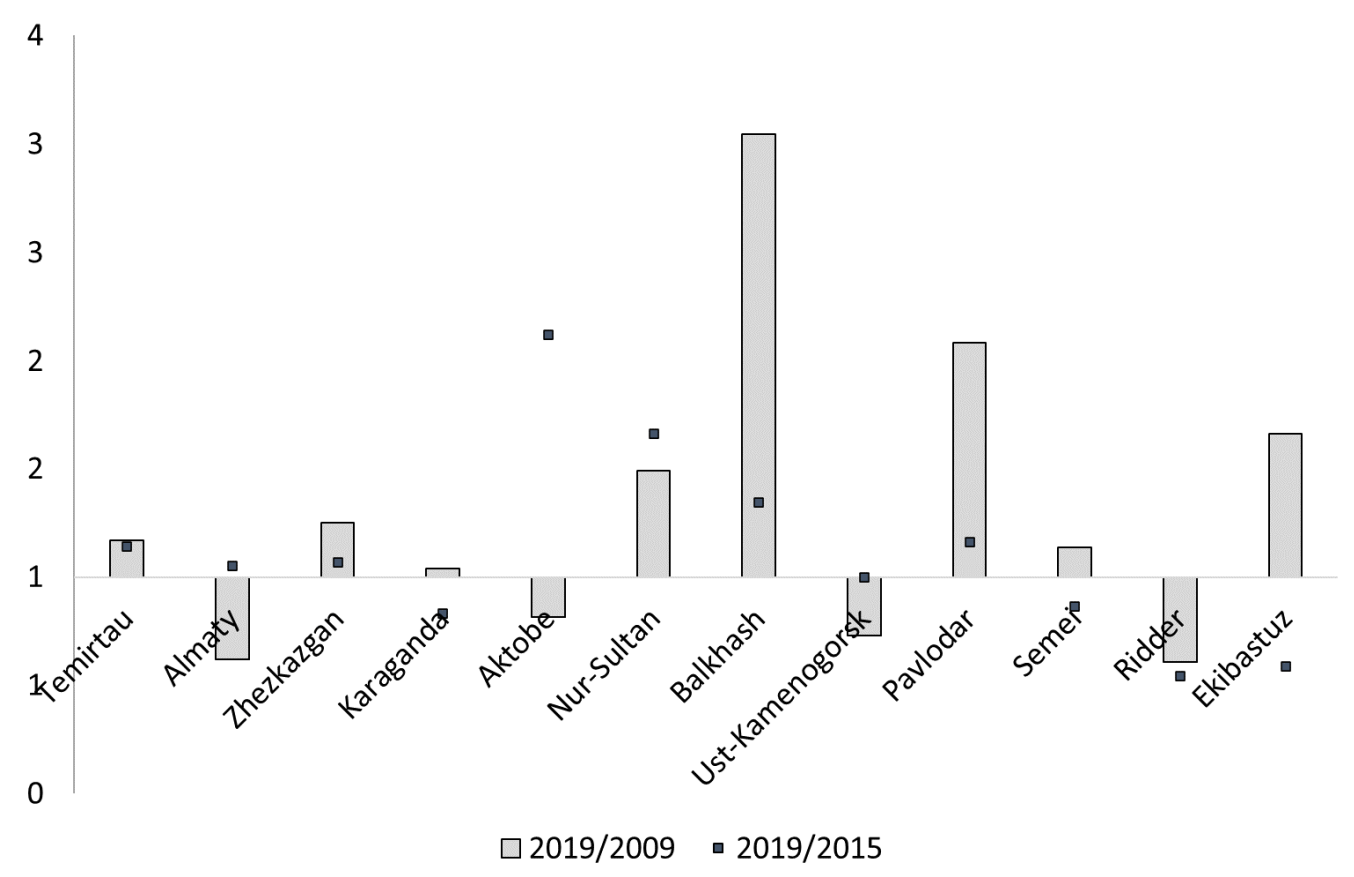

Figure 2. Changes in the air pollution index over 2015-2019 and 2009-2019 in the cities of Kazakhstan Source: [33].

The average annual concentration of TSP was extremely high in the cities in Kazakhstan: in ten cities (out of twelve), it was higher than $100 \mathrm{\mu g} \mathrm{m}^{-3}$ (Figure 3). The WHO has not established limit values for TSP, and the average annual concentrations of pollutants were compared with the nationally adopted average daily MAC only. Five cities exceeded the nationally adopted MAC for TSP $\left(150 \mu \mathrm{g} \mathrm{m}^{-3}\right)$. In Temirtau, the exceedance of the national MAC values was recorded for all the analyzed pollutants (TSP, $\mathrm{NO}_{2}$, and $\mathrm{SO}_{2}$ ). Ekibastuz and Pavlodar, which rank second and third in gross emissions, had lower TSP, $\mathrm{NO}_{2}$, and $\mathrm{SO}_{2}$ concentrations than other cities. This could be explained by the industrial enterprises being located far from the air quality monitoring stations, meteorological conditions, possible mistakes in the air quality data, and other factors. For example, the Pavlodar aluminum smelter with CHP- 1 is not covered by the air quality monitoring network, and the largest power plants in Aksu and Ekibastuz are 3 and $30 \mathrm{~km}$, respectively, away from the monitoring site. The relatively low air pollution levels in Ekibastuz, Aksu, and Rudnyi were partly due to the presence of only 1-3 monitoring stations. The World Bank [13] recommended that Kazakhstan extend its air quality monitoring network, especially in industrial cities.

The average annual concentrations of $\mathrm{NO}_{2}$ and $\mathrm{SO}_{2}$ in 2019 in fourteen cities in Kazakhstan are presented in Figure 3. Exceedance of the nationally established daily MAC values for $\mathrm{SO}_{2}\left(50 \mu \mathrm{g} \mathrm{m}^{-3}\right)$ and $\mathrm{NO}_{2}\left(40 \mu \mathrm{g} \mathrm{m}^{-3}\right)$ was recorded in three cities: Almaty, UstKamenogorsk, and Temirtau. The levels in these cities were clearly beyond the acceptable range, as they were higher than those in other cities in Kazakhstan. These three cities have coal-fired power plants, and two of them (Ust-Kamenogorsk and Temirtau) also have metallurgical enterprises. If we compare the concentration values with the WHO standard (24-h limit value for $\mathrm{SO}_{2}=20 \mu \mathrm{g} \mathrm{m}^{-3}$ ), the situation becomes more dramatic, as the annual average concentration was exceeded in seven cities in Kazakhstan-by a factor of 6.4 in Almaty $\left(128 \mu \mathrm{g} \mathrm{m}^{-3}\right), 4.5$ in Ust-Kamenogorsk $\left(90 \mu \mathrm{g} \mathrm{m}^{-3}\right), 2.9$ in Temirtau $\left(58 \mu \mathrm{g} \mathrm{m}^{-3}\right)$, and 2.2 in Ridder $\left(43 \mu \mathrm{g} \mathrm{m}^{-3}\right)$. Cities with high $\mathrm{SO}_{2}$ levels (Almaty, Ust-Kamenogorsk, Temirtau, Ridder) have coal power plants and/or heavy industrial plants.

To compare variations in concentrations in winter and summer, we used the monthly average concentrations of TSP, $\mathrm{SO}_{2}$, and $\mathrm{NO}_{2}$ in December, January, February, June, July, and August in 2019 (Table 4). Transitional months were excluded, as the heating season 
varies greatly between cities. Differences between winter and summer were significant, and the differences varied by city and pollutant.

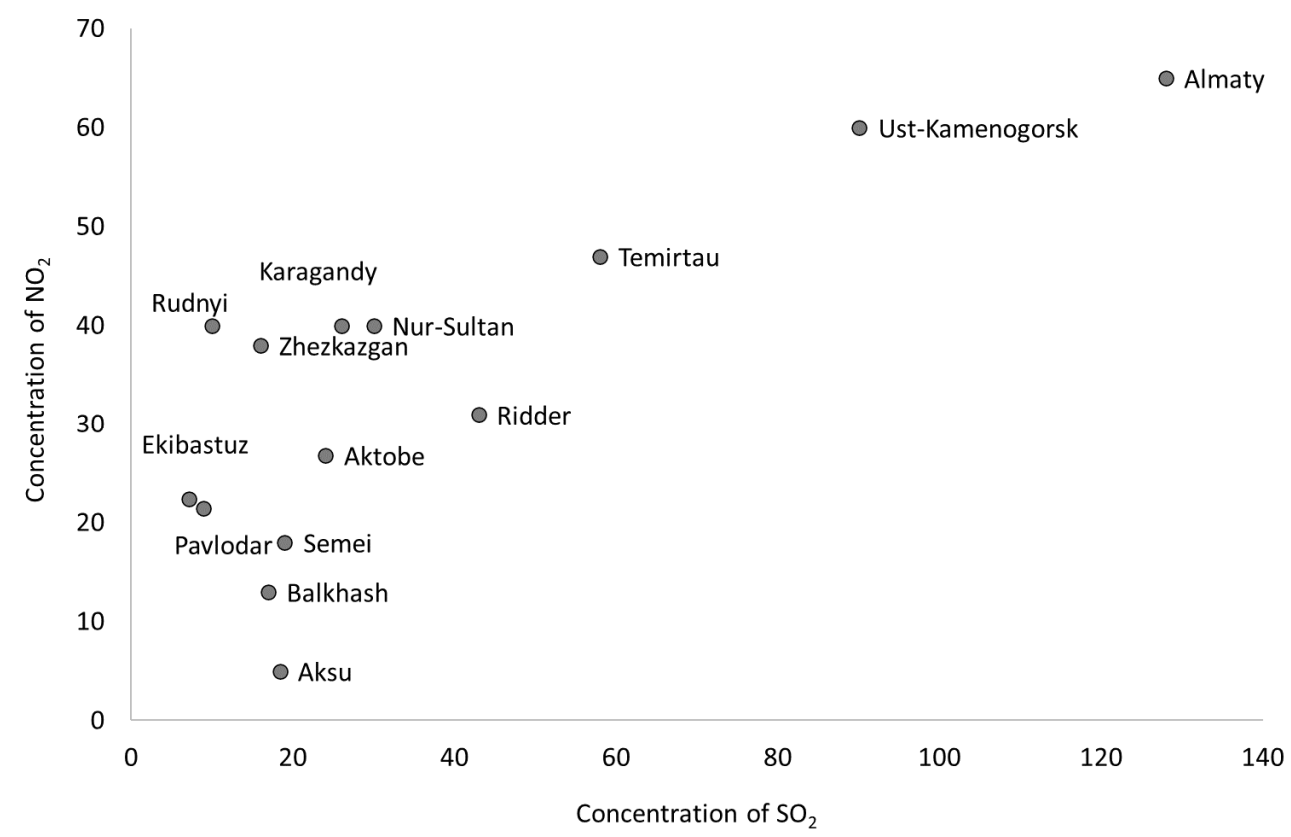

Figure 3. Average annual concentrations of $\mathrm{SO}_{2}$ and $\mathrm{NO}_{2}$ in cities in Kazakhstan in 2019, $\mu \mathrm{g} \mathrm{m}^{-3}$. Data source: [33].

Table 4. Monthly average concentration of pollutants by selected cities in $2019, \mu \mathrm{g} \mathrm{m}{ }^{-3}$.

\begin{tabular}{|c|c|c|c|c|c|c|c|c|c|}
\hline \multirow{2}{*}{ City } & \multicolumn{9}{|c|}{$\mathrm{TSP}, \mu \mathrm{g} \cdot \mathrm{m}^{-3}$} \\
\hline & Dec & Jan & Feb & Jun & Jul & Aug & Winter & Summer & \% Difference \\
\hline Almaty & 209 & 141 & 146 & 168 & 225 & 188 & 165 & 194 & 17.6 \\
\hline Ust-Kamenogorsk & 110 & 192 & 240 & 50 & 114 & 78 & 181 & 81 & -55.2 \\
\hline Temirtau & 281 & 294 & 313 & 305 & 248 & 255 & 296 & 269 & -9.1 \\
\hline Ridder & 70 & 100 & 100 & 100 & 100 & 100 & 90 & 100 & 11.1 \\
\hline Nur-Sultan & 100 & 400 & 100 & 200 & 170 & 100 & 200 & 157 & -21.5 \\
\hline Karaganda & 166 & 135 & 142 & 97 & 151 & 152 & 148 & 133 & -10.1 \\
\hline Balkhash & 123 & 177 & 120 & 200 & 203 & 160 & 140 & 188 & 34.3 \\
\hline Zhezkazgan & 274 & 200 & 6 & 510 & 492 & 453 & 160 & 485 & 203.1 \\
\hline Pavlodar & 112.1 & 51.4 & 61.5 & 160 & 143 & 112 & 75 & 138 & 84 \\
\hline Ekibastuz & 118.8 & 61.1 & 84.9 & 240 & 147 & 130 & 88 & 172 & 95.5 \\
\hline Aktobe & 0 & 17.9 & 16.5 & 23 & 15 & 13 & 11 & 17 & 54.5 \\
\hline Semei & 101 & 87 & 120 & 94 & 72 & 117 & 103 & 94 & -8.7 \\
\hline \multirow{2}{*}{ City } & \multicolumn{9}{|c|}{$\mathrm{SO}_{2}, \mu \mathrm{g} \cdot \mathrm{m}^{-3}$} \\
\hline & Dec & Jan & Feb & Jun & Jul & Aug & Winter & Summer & $\%$ Difference \\
\hline Almaty & 240 & 39 & 48 & 128 & 165 & 165 & 109 & 153 & 40.4 \\
\hline Ust-Kamenogorsk & 117 & 123 & 110 & 50 & 111 & 102 & 117 & 88 & -24.8 \\
\hline Temirtau & 48 & 105 & 75 & 30 & 73 & 35 & 76 & 46 & -39.5 \\
\hline Ridder & 47 & 57 & 49 & 30 & 35 & 45 & 51 & 37 & -27.5 \\
\hline Nur-Sultan & 90 & 20 & 20 & 10 & 10 & 10 & 43 & 10 & -76.7 \\
\hline Karaganda & 28 & 36 & 33 & 20 & 24 & 24 & 32 & 23 & -28.1 \\
\hline Aktobe & 15.4 & 22.3 & 81.8 & 23 & 24 & 36 & 40 & 28 & -30 \\
\hline Aksu & 21 & 21 & 22.6 & 17 & 16 & 16 & 22 & 16 & -27.3 \\
\hline Balkhash & 14 & 11 & 9 & 19 & 6 & 20 & 11 & 15 & 36.4 \\
\hline Zhezkazgan & 10 & 7 & 42 & 15 & 14 & 14 & 20 & 14 & -30 \\
\hline Pavlodar & 10.3 & 8.6 & 7.6 & 10.6 & 8 & 5 & 9 & 8 & -11.1 \\
\hline Ekibastuz & 8.6 & 6.4 & 8.7 & 6 & 5 & 5 & 8 & 5 & -37.5 \\
\hline Semei & 25 & 39 & 29 & 20 & 18.6 & 13 & 31 & 17 & -45.2 \\
\hline
\end{tabular}


Table 4. Cont.

\begin{tabular}{|c|c|c|c|c|c|c|c|c|c|}
\hline \multirow{2}{*}{ City } & \multicolumn{9}{|c|}{$\mathrm{NO}_{2}, \mu \mathrm{g} \cdot \mathrm{m}^{-3}$} \\
\hline & Dec & Jan & Feb & Jun & Jul & Aug & Winter & Summer & \% Difference \\
\hline Almaty & 118 & 63 & 69 & 51 & 52 & 48 & 83 & 50 & -39.8 \\
\hline Ust-Kamenogorsk & 65 & 10 & 60 & 54 & 70 & 65 & 45 & 63 & 40 \\
\hline Temirtau & 28 & 129 & 143 & 18 & 19 & 20 & 100 & 19 & -81 \\
\hline Ridder & 33 & 35 & 32 & 20 & 28 & 32 & 33 & 27 & -18.2 \\
\hline Nur-Sultan & 40 & 50 & 30 & 40 & 50 & 40 & 40 & 43 & 7.5 \\
\hline Karaganda & 44 & 37 & 38 & 36 & 39 & 45 & 40 & 40 & 0 \\
\hline Aktobe & 30 & 30.3 & 37.9 & 20 & 22 & 23 & 33 & 22 & -33.3 \\
\hline Aksu & 0.6 & 10.7 & 7 & 10 & 2 & 2 & 6 & 5 & -16.7 \\
\hline Balkhash & 9 & 9 & 12 & 20 & 15 & 13 & 10 & 16 & 60 \\
\hline Zhezkazgan & 42 & 42 & 2 & 41 & 36 & 32 & 29 & 36 & 24.1 \\
\hline Rudnyi & 40 & 40 & 4.8 & 30 & 30 & 40 & 28 & 33 & 17.9 \\
\hline Pavlodar & 21.8 & 31.3 & 21.3 & 13 & 16 & 25 & 25 & 18 & -28 \\
\hline Ekibastuz & 30.1 & 29.2 & 24.1 & 14 & 15 & 20 & 28 & 16 & -42.9 \\
\hline Semei & 22 & 19 & 24 & 17 & 16 & 18 & 22 & 17 & -22.7 \\
\hline
\end{tabular}

Seasonal variations in air pollution can be highly affected by meteorology. Two meteorological parameters (temperature and relative humidity) by months and by cities are presented in Appendix A, Tables A2 and A3. The climate of Kazakhstan is continental, with cold winters and hot summers. The average temperature significantly varies from the northern to southern regions of Kazakhstan. The average winter temperature in the selected cities located in the north and central areas was $-12-14{ }^{\circ} \mathrm{C}$ and it was $-4{ }^{\circ} \mathrm{C}$ in Almaty (the only city considered in this study which is located in the south). Heating is a basic need for survival in Kazakhstan, therefore the amount of fuel consumption is higher in the winter time due to the additional demand for heating. In all selected cities there are coal-fired CHPs, except for three cities.

The concentration of TSP increased in seven cities in the summer compared to the winter. This is an unexpected result because the level of emissions from CHPs and residential heating is generally higher in the winter-time. On the other hand, the level of emissions from metallurgical enterprises and transportation could be stable throughout the year. CHPs in Almaty and Nur-Sultan annually burn around 3.7 and 3.2 million tons of coal respectively. The operation of the CHPs depends on the outside temperature. As an example, the average daily coal consumption in Almaty CHP-2 was more than twice as high in the winter period compared to summer, 9424 tons/day in January 2019 and 3999 tons/day in July 2019. Stable atmospheric conditions and temperature inversions could lead to winter-time episodic pollution. In Almaty the level of TSP was 17.6\% lower in winter compared to the summer in 2019 (Table 4). On the contrary, independent air quality monitoring from the airkaz.org website depicted that the average level of $\mathrm{PM}_{2.5}$ concentration in winter in Almaty was $110 \mu \mathrm{g} \mathrm{m}^{-3}$, which was nearly 6 times higher than in the summer $\left(18 \mu \mathrm{g} \mathrm{m}^{-3}\right)$. Such differences in seasonal variations of TSP and $\mathrm{PM}_{2.5}$ from two sources: official Kazhydromet's TSP values and civil activists' $\mathrm{PM}_{2.5}$ measurements need further investigation. TSP values cannot be directly compared to $\mathrm{PM}_{2.5}$, the ratio $\mathrm{PM}_{2.5}$ /TSP can vary by seasons, with fine particles originating from the combustion of fuels and coarse particles from soils and, road dust resuspension. Another possible explanation could be that in the cities under consideration, the average relative air humidity in the summer months was $16-47 \%$ lower than in the winter (Table A3). At high air humidity, the process of deposition of fine particles could occur faster due to their coagulation.

On the contrary, $\mathrm{SO}_{2}$ declined in the summertime compared to the winter period in eleven cities. $\mathrm{NO}_{2}$ concentration was lower in the summertime in eight cities. Higher levels of $\mathrm{NO}_{2}$ and $\mathrm{SO}_{2}$ levels in the winter time were not a surprise, especially in the areas with coal-fired CHPs and households burning coal for heating.

No data is available on the industrial activity by seasons; therefore explaining the factors contributing to the seasonal variations needs further investigation. 


\subsection{Emissions Trends from Stationary Sources}

Between 2009 and 2018, $\mathrm{NO}_{\mathrm{x}}, \mathrm{CO}$, and $\mathrm{SO}_{2}$ emissions increased significantly by $32 \%$, $10 \%$, and $8 \%$, respectively (Table 5). Paradoxically, there was a decline in TSP emissions by $32 \%$ over this period but an increase in inorganic dust $\left(\mathrm{SiO}_{2} 70-20 \%\right)$ by $67 \%$. This could be partially explained by the fact that, in Kazakhstan, when coal is burned at power plants methodologies prescribe that ash dust be standardized as inorganic dust $\left(\mathrm{SiO}_{2} 70-20 \%\right)$. The increase in the emissions of inorganic dust $\left(\mathrm{SiO}_{2} 70-20 \%\right)$ in Kazakhstan could be due to the increase in coal consumption at coal-fired power plants over the same period. Emissions of TSP in Kazakhstan are estimated mainly at metallurgical enterprises and in the construction industry. The decline in the TSP emissions from stationary sources for the period 2009-2018 may be explained by the fact that some industrial plants started to report TSP as inorganic dust $\left(\mathrm{SiO}_{2} 70-20 \%\right)$, but this assumption needs further verification.

Table 5. Emissions of priority pollutants from stationary sources in 2009-2018 in Kazakhstan. Data source: [9,10].

Emissions of Pollutants into the Atmosphere by Year, Thousand Tons/Year

\begin{tabular}{|c|c|c|c|c|c|c|c|c|c|c|c|}
\hline & 2009 & 2010 & 2011 & 2012 & 2013 & 2014 & 2015 & 2016 & 2017 & 2018 & $\%$ \\
\hline Total emissions & 2320 & 2227 & 2346 & 2384 & 2283 & 2257 & 2180 & 2272 & 2358 & 2447 & $5 \%$ \\
\hline $\mathrm{SO}_{2}$ & 780 & 724 & 774 & 770 & 729 & 729 & 711 & 767 & 786 & 838 & $8 \%$ \\
\hline $\mathrm{CO}$ & 433 & 401 & 445 & 446 & 458 & 479 & 451 & 473 & 492 & 477 & $10 \%$ \\
\hline NOx & 207 & 216 & 233 & 249 & 250 & 257 & 243 & 247 & 265 & 272 & $32 \%$ \\
\hline TSP & 40 & 41 & 42 & 46 & 42 & 38 & 37 & 33 & 31 & 27 & $-32 \%$ \\
\hline $\begin{array}{l}\text { Inorganic dust } \\
\left(\mathrm{SiO}_{2} 70-20 \%\right)\end{array}$ & & 204 & 260 & 259 & 317 & 314 & 303 & 312 & 324 & 340 & $67 \%$ \\
\hline $\begin{array}{l}\text { Inorganic dust } \\
\left(\mathrm{SiO}_{2}>70 \%\right)\end{array}$ & 50 & 76 & 25 & 23 & 18 & 20 & 18 & 13 & 11 & 11 & $-79 \%$ \\
\hline $\begin{array}{c}\text { Inorganic dust } \\
\left(\mathrm{SiO}_{2}<20 \%\right)\end{array}$ & & & & & & & & 30 & 40 & 85 & $183 \%$ \\
\hline $\begin{array}{l}\text { Coal ash from } \\
\text { power plants }\end{array}$ & 26 & 47 & 48 & 35 & 19 & 14 & 9 & 9 & 14 & 14 & $-48 \%$ \\
\hline
\end{tabular}

Kazakhstan inherited a system for setting emissions and hygienic standards for pollutants from the Soviet Union. There was no separation of dust into $\mathrm{PM}_{2.5}$ and $\mathrm{PM}_{10}$, therefore MACs were developed for certain types of dust, typical for the main types of industries. No attention was paid to the size of particles. The concept of $\mathrm{PM}_{2.5}$ and $\mathrm{PM}_{10}$ appeared in the legislative documents of Kazakhstan only in 2012, but there are still no requirements for reporting and estimating dust by particle size. The concept of inorganic dust with different contents of silicon dioxide is used only in post-Soviet countries. In the sanitary rules of Kazakhstan, an explanation is given of the cases to normalize which types of dust:

- Coal ash from thermal power plants (with a calcium oxide content of 35-40\%);

- Inorganic dust $\mathrm{SiO}_{2}>70 \%$ if the mass fraction of $\mathrm{SiO}_{2}$ in the dust composition exceeds $70 \%$;

- Inorganic dust $\mathrm{SiO}_{2} 70-20 \%$ if the mass fraction of $\mathrm{SiO}_{2}$ in the dust composition ranges from $20-70 \%$ (clinker, ash, blast furnace slag, sand, clay);

- Inorganic dust $\mathrm{SiO}_{2}<20 \%$ if the mass fraction of $\mathrm{SiO}_{2}$ in the dust is up to $20 \%$ (bauxite, cinder, dolomite, limestone).

In fact, when industrial plants report emissions of dust, the composition of the dust is not checked by the authorities. All these types of dust affect the concentration of TSP, $\mathrm{PM}_{2.5}$, and $\mathrm{PM}_{10}$ in the ambient air. To eliminate confusion, when standardizing dust, 
which is currently named as "inorganic dust $\left(\mathrm{SiO}_{2} 70-20 \%\right)$ ", "inorganic dust $\left(\mathrm{SiO}_{2}>70 \%\right)$ ", "inorganic dust $\left(\mathrm{SiO}_{2}<20 \%\right)$ ", "coal ash from power plants" and "TSP" should be unified in accordance with international definitions of pollutants. Those definitions of dust (inorganic dust $\left(\mathrm{SiO}_{2} 70-20 \%\right)$, inorganic dust $\left(\mathrm{SiO}_{2}>70 \%\right)$, inorganic dust $\left(\mathrm{SiO}_{2}<20 \%\right)$, coal ash from power plants) are outdated, as they have been used since the USSR period.

\subsection{Links between Air Quality in the Cities and Industrial Emissions}

To establish links between air quality in the cities with the activity of the industrial plants, the available data on air pollution levels (API) were compared with the data on industrial emissions. Emissions from stationary sources by cities reported in the Statistical Publication "Environmental Protection and Sustainable Development of Kazakhstan" [9,10] were employed. Gross emissions stationary sources were used because emissions by each pollutant by cities are not available.

For fourteen cities, there was no correlation $\left(\mathrm{R}^{2}=0.0256, p=0.58\right)$ found between API level and industrial emissions (Figure 4). In Kazakhstan, the availability of monitoring systems is insufficient; particularly in small industrial cities. In Ekibastuz, Aksu, and Rudnyi there are only one to three monitoring stations. Pavlodar aluminum smelter is not covered by the monitoring system of Pavlodar city. In Aksu and Ekibastuz, monitoring stations are located at a distance of 3 and $30 \mathrm{~km}$ from the enterprises.

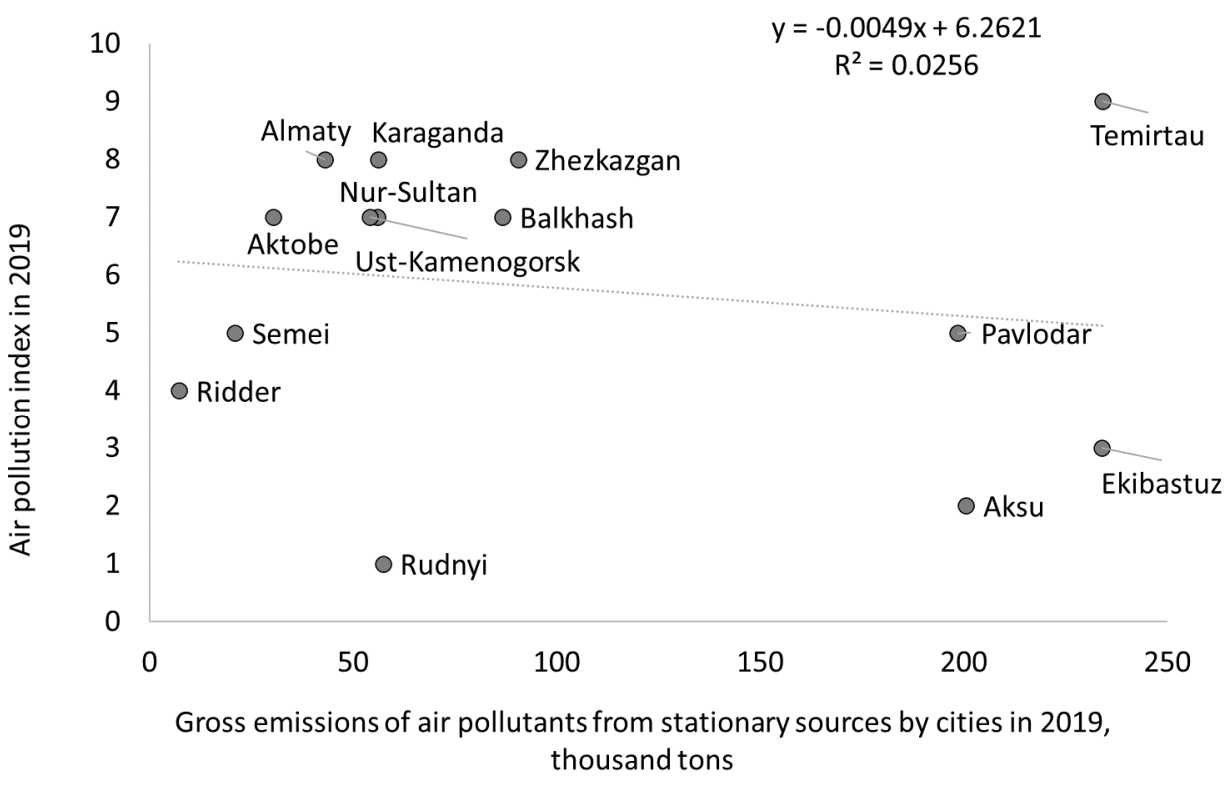

Figure 4. Air pollution index and gross emissions from stationary sources in 2019 for fourteen cities of Kazakhstan.

If we exclude four cities (Pavlodar, Ekibastuz, Aksu, Rudnyi) where industrial plants are located outside of the city and where there is a lack of monitoring stations, the situation is dramatically different (Figure 5). API level and gross emissions were correlated $\left(R^{2}=0.4791, p=0.027\right)$ for the remaining ten cities, although the correlation was not strong. This could indicate a contribution of industrial emissions in the air pollution of the cities.

The results also showed the importance of high spatial coverage of the air quality monitoring network, especially in polluted industrial cities. The World Bank (2013) also highlighted the lack of an air quality monitoring network in the industrial cities of Kazakhstan [13]. Despite the high level of industrial emissions in Aksu and Ekibastuz cities (more than 200 thousand tons), the API level was low (API two and three), possibly because the industrial plants are located outside the cities. Results indicated that the location of industrial plants far outside the cities could reduce the exposure of the population of the cities to air pollution. 


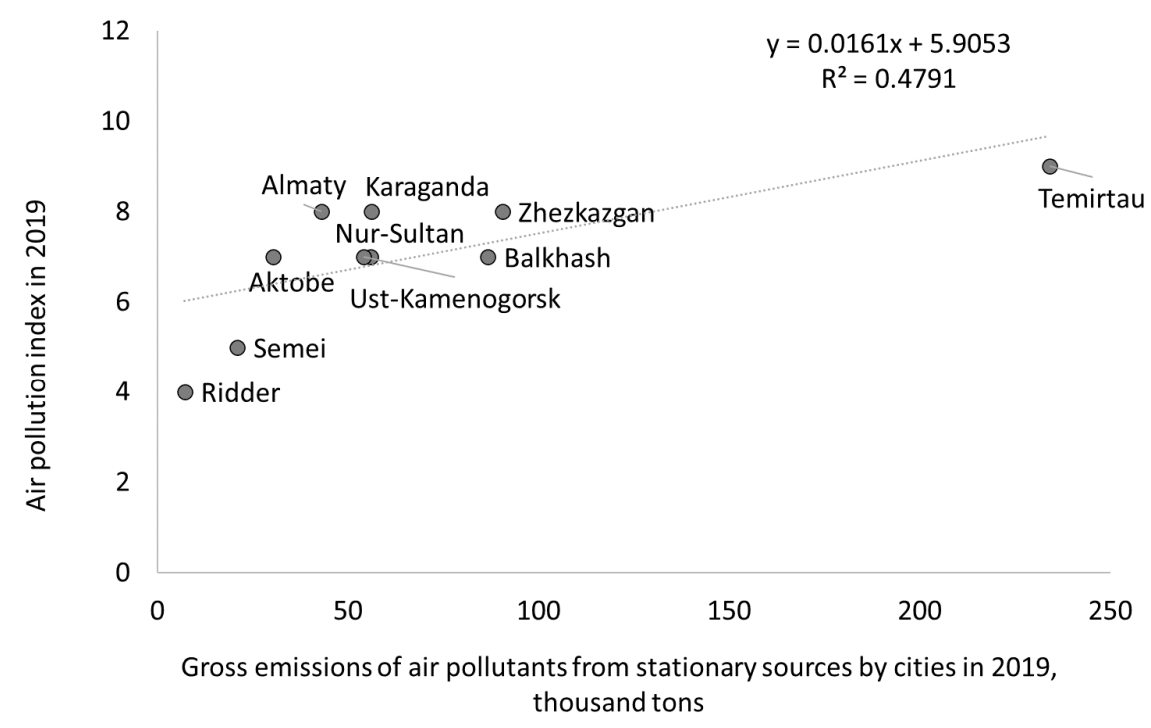

Figure 5. Air pollution index and gross emissions from stationary sources in 2019 for ten cities of Kazakhstan.

\subsection{Other Possible Factors Contributing to Air Pollution}

Topography and meteorological factors could play an important role in air pollution. Almaty and Ust-Kamenogorsk cities are located in the bowl of mountain ranges. It causes a large number of windless days. The rest of the considered industrialized cities are located mainly in the steppe zone.

Winter smog episodes in Nur-Sultan have common meteorological conditions and anticyclonic conditions (with low wind speed, high ground-level pressures, freezing weather conditions with the air temperature reaching $-30{ }^{\circ} \mathrm{C}$ at night and $-20^{\circ} \mathrm{C}$ in the daytime over several days) [12].

There are also natural sources of air pollution, such as dust blown from soils. Desert and semi-desert areas of Kazakhstan are mainly located in the areas of the Caspian Sea and southern parts of Kazakhstan. Issanova and Abuduwaili [36] and Nobakht et al. [37] note that sandstorms in Kazakhstan are common in South Kazakhstan (the Syr Darya and Ile river valleys), the southern part of Lake Balkhash. Zhang et al. [38] found that the main source of Aeolian Dust in Central Asia is the Aral Sea (southwestern Kazakhstan), which has significantly dried up since the 1960s. The selected cities in this study are located in the northern parts of Kazakhstan (except for Almaty) in the steppe and forest-steppe zones and those areas could be less affected by frequent sandstorms.

Transport could be one of the important sources of air pollution, particularly in densely populated large cities. The number vehicles per 100 persons increased in Kazakhstan from 4.7 units in 1990 to 19.2 units in 2019. The rapid increase in the number of passenger cars can be attributed to inefficient public transport and a lack of alternatives for the population. None of the cities in Kazakhstan have high-speed public transport modes (e.g., metro, LRT). There is a metro system in Almaty, but it has only 9 stations with $11.5 \mathrm{~km}$ length. Two densely populated cities (Almaty and Nur-Sultan) have the highest number of registered vehicles: 514 and 300 thousand vehicles respectively [39].

Selected cities, except for Almaty and Nur-Sultan, are small industrial cities. Seven cities (out of fourteen) have a low population (less than 179 thousand people) and have less than 41 thousand registered vehicles. The number of registered vehicles by cities was compared with the API in the selected cities (Figure 6). Transport in Almaty and Nur-Sultan could have a contribution to air pollution deterioration, while in other cities non-transportation sources may dominate in the contribution to air pollution. The correlation between the number of registered vehicles and API was low $\left(R^{2}=0.151, p=0.189\right)$. Temirtau, Zhezkazgan, and Balkhash have high levels of air pollution, despite the very low population and fewer transport vehicles. 


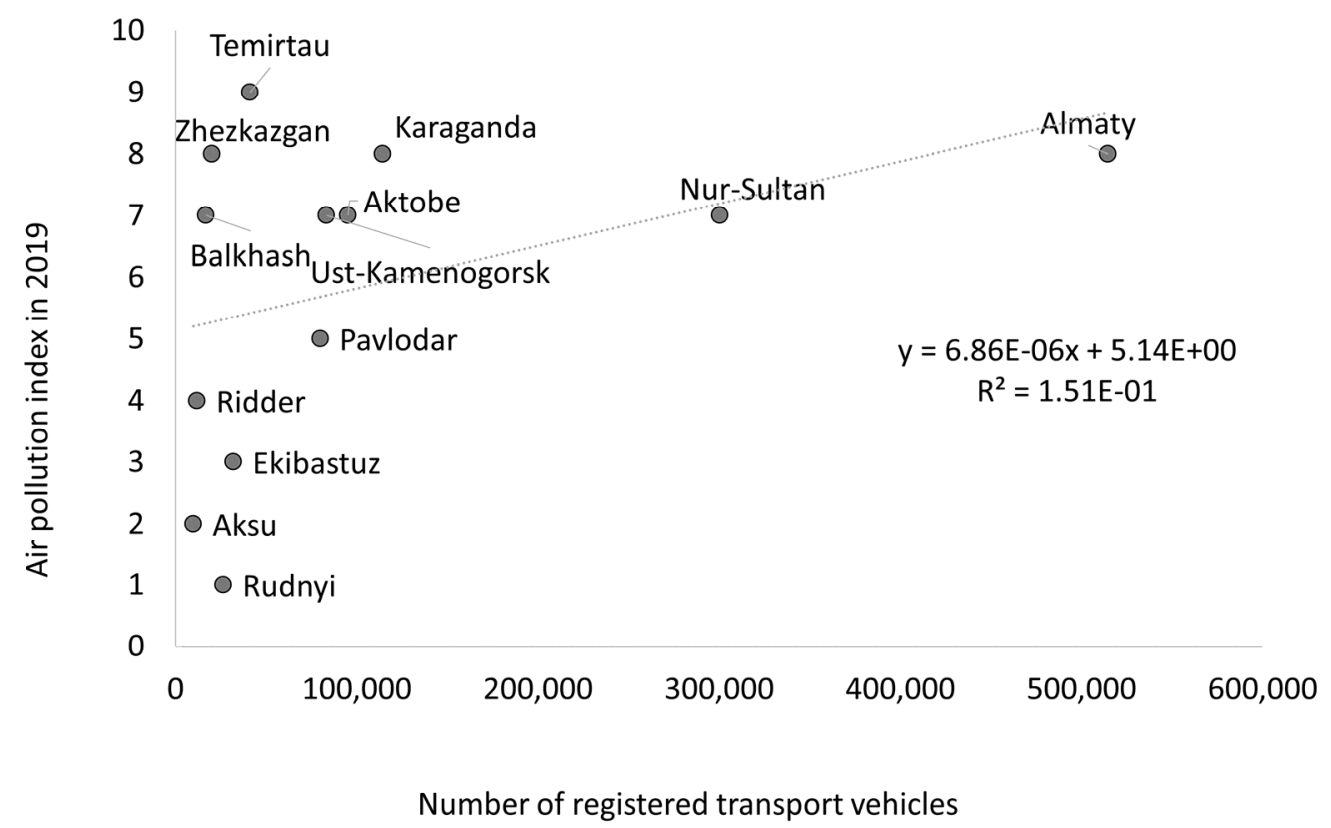

Figure 6. Number of registered vehicles by cities and API in 2019.

Coal combustion for household heating is also an important source of air pollution. The households Survey showed that solid fuels (coal and firewood) are mainly used by rural households: $55 \%$ of rural households in Kazakhstan used solid fuels and only $17 \%$ of urban households used solid fuels [40]. The data on the share of households using coal by cities were compared to with the Air Pollution Index by cities (Figure 7). It could be observed that despite the low share of households using coal in Almaty (1\%) and NurSultan $(6 \%)$, those cities remain highly polluted. Generally in the selected cities, the share of households using coal was less than $25 \%$. There is no available data for small cities such as Semei, Rudnyi, Aksu, and Ridder.

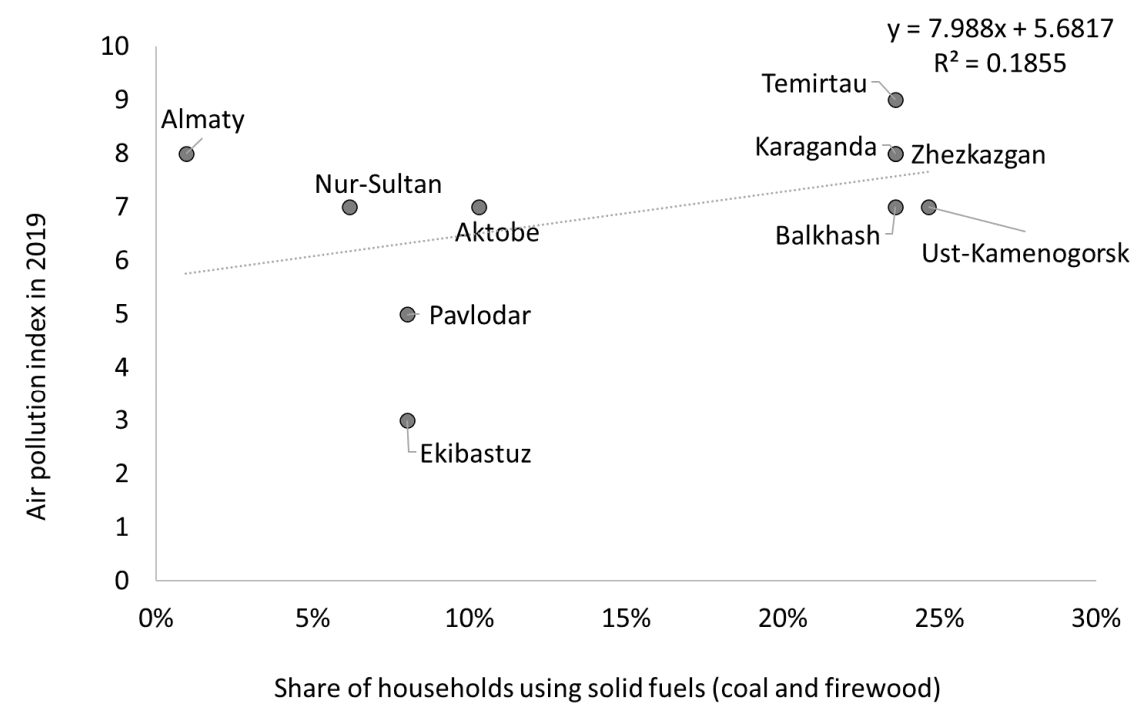

Figure 7. Share of households using coal and API in 2019.

Out of fourteen cities, only two cities have access to network gas: Aktobe and Almaty. Households could be significant sources of $\mathrm{PM}_{2.5}, \mathrm{SO}_{2}, \mathrm{NO}_{\mathrm{x}}$ emissions in the cities of Kazakhstan. However, in Kazakhstan, household emissions are not estimated, since, according to Article 10 of the Environmental Code [6], they are referred to as the general use of natural resources, which is free and not subject to regulation. The volume of household emissions is currently not established in Kazakhstan. 
Emissions inventory and source-apportionment studies need to be conducted in the cities of Kazakhstan to quantify the impact of the sources of air pollution. The impact of topography and meteorology factors also needs further investigation.

\subsection{Emission Limit Values of Selected Industrial Enterprises}

In the nine major metallurgical enterprises considered, there was an overall increase in ELV by 124 thousand tons per year (23\% increase). A reduction in the ELV was observed for only three enterprises, totaling 11 thousand tons, while the ELV increased by 135 thousand tons for five enterprises (Figure 8).

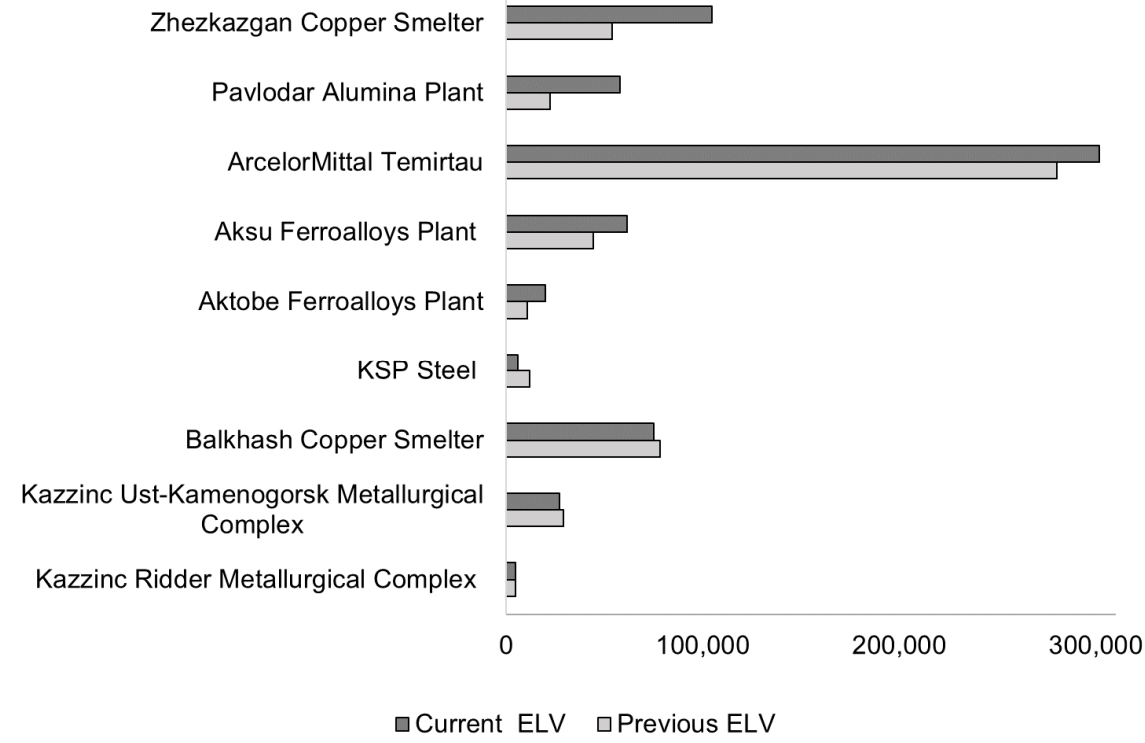

Figure 8. Changes in the emission limit values (ELVs) of the metallurgical enterprises, tons. Data source: Emissions permitting documents of the enterprises.

For the twenty-one power plants considered, there was an overall increase in ELV amounting to 66 thousand tons per year ( $7 \%$ change). Thirteen power plants increased their ELV by a total of 152 thousand tons. There was no change at three power plants. Emissions reductions were found for only five power plants, totaling 86 thousand tons (Figure 9).

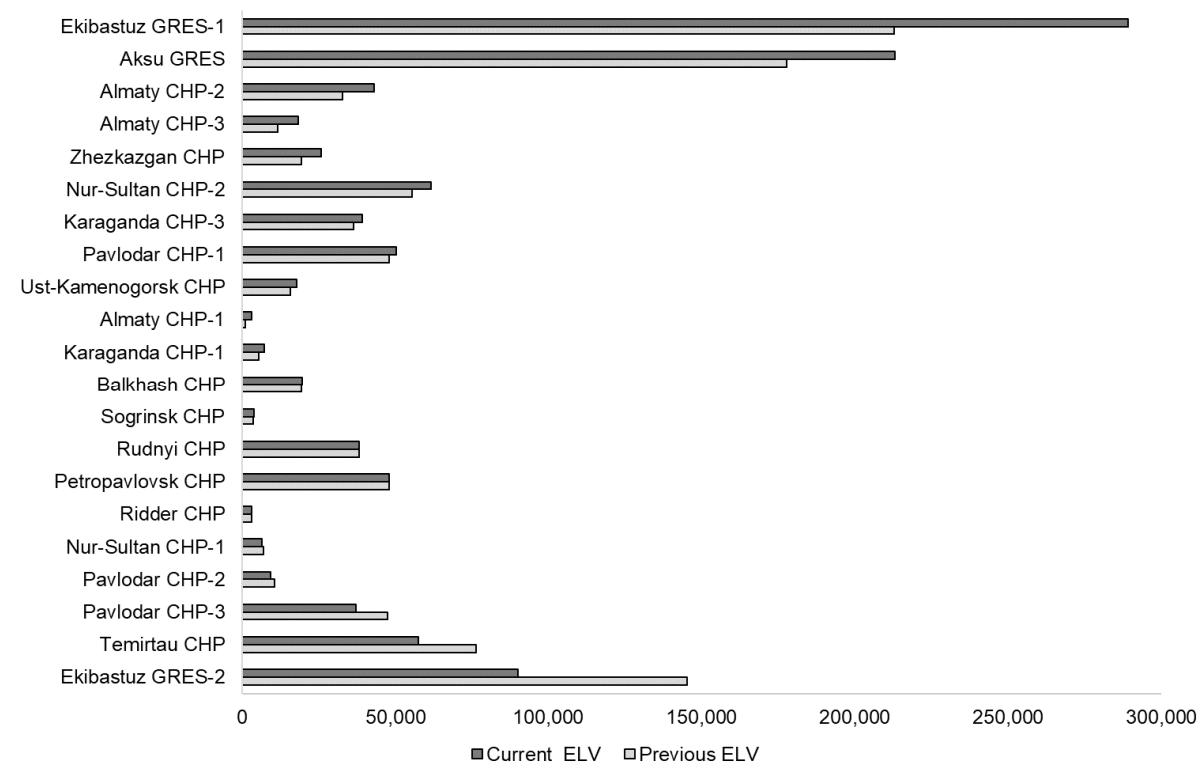

Figure 9. Changes in the ELVs of the power plants, tons. Data source: Emissions permitting documents of the enterprises. 
The used data proved the inefficiency of the air protection policy at major thermal power plants. Authorities permit enterprises to increase their consumption of coal without obliging them to implement special measures for reducing their emissions of harmful substances into the atmosphere.

Permitting documents often do not contain activity data. Therefore, it was not possible to compare emissions per unit of output with the best practices in the sector. Permits contain data on coal consumption by power plants per year (at maximum production output). Therefore, ELVs per unit of coal use have been analyzed in this study (Table A1). It could be observed that there were large variations in emissions per unit of coal consumed across power plants. As an example, allowed emissions, i.e., the $\mathrm{ELV}$ of $\mathrm{SO}_{2}$ were between 9 to $34 \mathrm{~kg} /$ ton of oil equivalent (toe), allowed emissions of ash were between 3 to $24 \mathrm{~kg} / \mathrm{ton}$. Such variations in emissions intensities across power plants could be related to gaps in methodology for the determination of the ELV, which do not require emissions per unit of activity to be estimated and compared with best practices in the sector. There is no practice of benchmarking the environmental performance of industrial plants in terms of their emissions per unit of activity data due to the lack of data, lack of expertise, and absence of such a requirement in the legislation.

\section{Discussion}

Cities selected for this study were heavily polluted in 2019: the concentration of TSP exceeded $100 \mathrm{\mu g} \mathrm{m}^{-3}$ in ten (out of twelve) cities, and the concentration of $\mathrm{SO}_{2}$ exceeded $20 \mu \mathrm{g} \mathrm{m}^{-3}$ in seven (out of fourteen) cities. Annual average $\mathrm{SO}_{2}$ concentration levels were very high in Almaty $\left(128 \mu \mathrm{g} \mathrm{m}^{-3}\right)$, in Ust-Kamenogorsk $\left(90 \mu \mathrm{g} \mathrm{m}^{-3}\right)$, and in Temirtau $\left(58 \mu \mathrm{g} \mathrm{m}^{-3}\right)$. Eight cities (out of fourteen) have a "high" level of air pollution according to the Air Pollution Index (API). Winter to summer variation was considerable, and the differences varied by the cities and by the pollutants. Seasonal variations are hard to explain, due to the lack of data on industrial activity by seasons.

Non-industrial emission sources were also discussed in this study. Transport is unlikely to be a major contributor to air pollution in the selected cities, except for Almaty and Nur-Sultan.

For fourteen cities, there was no correlation found between air pollution level and industrial emissions. If we exclude four cities where industrial plants are located outside the city and where there is a lack of monitoring stations, API level and gross industrial emissions would correlate $\left(R^{2}=0.4791\right)$, although not strongly. Results indicate the need for expanding the coverage of the air quality monitoring network in the industrial cities of Kazakhstan.

Despite a high level of industrial emissions in Aksu and Ekibastuz cities (more than 200 thousand tons), the API level was low, possibly because the industrial plants are located outside the cities. Results indicate that the location of the industrial plants far outside of cities could reduce the exposure of the population of the cities to air pollution.

In this study, it was demonstrated that the current emission permitting system does not provide an effective mechanism for emissions reduction. Most of the considered enterprises increased their emission limit values. Although the primary legislation, in theory, provides a framework for environmental protection, there are several loopholes in the secondary legislation: the methods for determining ELVs are linked to weak environmental quality standards, and there is a lack of monitoring and law enforcement. The increase in allowed emissions for coal power plants was explained by the growth of heat and electricity consumption and investment programs to increase production capacities. Power plants were not required to reduce emissions or introduce emission control technologies for reducing $\mathrm{NO}_{2}$ and $\mathrm{SO}_{2}$ emissions. Considering the quality of ambient air in the cities, it would be rational to assume that no increase in emissions should be permitted for coal power plants.

The air quality standards adopted in Kazakhstan are outdated. For example, enterprises can legally generate emissions that lead to a $500 \mu \mathrm{g} \mathrm{m}{ }^{-3}$ concentration of $\mathrm{SO}_{2}$ at 
the border of the sanitary protection zone, which is twenty-five times higher than the 24-h average WHO limit value $\left(20 \mathrm{\mu g} \mathrm{m}^{-3}\right)$. Outdated methodologies for estimating and presenting data, such as the summing of pollutants with different levels of toxicity or using several definitions for dust, cause information on emissions and air quality levels to remain hidden and unclear. There is an urgent need to harmonize environmental quality standards and methodologies in Kazakhstan to collect and present environmental data in accordance with the latest scientific knowledge and international practices.

Stringent emissions standards for coal-fired power plants have been successful in other countries. In 2014, China introduced "ultra-low" emission standards for coal-fired power plants; by 2017, almost all coal-fired power plants in China had installed $\mathrm{NO}_{\mathrm{x}}$ and $\mathrm{SO}_{2}$ control devices [23]. Between 2014 and 2017, China's annual power emissions of $\mathrm{SO}_{2}$, $\mathrm{NO}_{\mathrm{x}}$, and $\mathrm{PM}$ reduced substantially by $65 \%, 60 \%$, and $72 \%$, respectively [23]. Stringent emissions standards for coal-fired power plants must be introduced in Kazakhstan.

Kazakhstan is planning to transition to an emission permit system based on technologyintegrated OECD practices. With the constant pressure from powerful industrial associations, it remains uncertain whether authorities would be able to push stricter industrial emissions regulations. Authorities have to ensure that Kazakhstan's list of BAT and technical emissions standards correspond with those from Europe.

Due to scarcity of funding for expensive laboratory equipment and lack of capacity, source apportionment with chemical analysis of PM particles has not been conducted for the cities of Kazakhstan so far.

Limitations of this study should be noted. The first limitation is the use of estimated emission values from permitting documents of power plants and industrial plants. Data on the real emissions from stationary sources in Kazakhstan are not available due to the absence of a continuous emissions monitoring system in industrial and power plants in Kazakhstan. The impact of meteorological factors and topography on the air quality levels in industrial cities should be investigated. Future studies should empirically examine the impact of industrial emissions permitting policy on air pollutant emissions. Appropriate source-apportionment studies should be conducted in heavily polluted areas.

Author Contributions: Data collection and analysis, original draft preparation have been made by D.A. Literature review, writing, final review, and editing have been made by A.K. Funding acquisition by V.Z. All authors have read and agreed to the published version of the manuscript.

Funding: This work was funded by a grant from the Ministry of Education and Science of the Republic of Kazakhstan № AP08053440 Research of emissions major sources of harmful substances into atmospheric air of Ust-Kamenogorsk with the cause identification of high hydrogen sulfide content. The work of Aiymgul Kerimray was supported by Postdoctoral Fellowship provided by Al-Farabi Kazakh National University.

Institutional Review Board Statement: Not applicable.

Informed Consent Statement: Not applicable.

Data Availability Statement: Annual concentration levels of pollutants and Air Pollution Index values are available at the website of Kazhydromet https://www.kazhydromet.kz/ru/ecology/ informacionnye-byulleteni-o-sostoyanii-okruzhayuschey-sredy-respubliki-kazahstan (accessed on 17 January 2021). Permitting documents of industrial enterprises were obtained from the conclusions of the state environmental expertise on the website of electronic licensing of Kazakhstan http:/ / elicense.kz/ (accessed on 23 April 2020). Data on emissions of priority pollutants from stationary sources are available at the website of the Committee of Statistics of the Ministry of National Economy of the Republic of Kazakhstan (2019) https: / stat.gov.kz/ (accessed on 17 January 2021).

Acknowledgments: We thank Zhanna Kapsalyamova for improving the English writing of the paper.

Conflicts of Interest: The authors declare no conflict of interest. 


\section{Appendix A}

Table A1. Information from approved ELV for selected power plants.

\begin{tabular}{|c|c|c|c|c|c|c|c|c|c|c|c|c|c|c|c|c|}
\hline \multirow{2}{*}{ № } & \multirow{2}{*}{ Name of Power Plant } & \multirow{2}{*}{$\begin{array}{l}\text { Electric } \\
\text { Capacity, } \\
\text { MW }\end{array}$} & \multirow{2}{*}{$\begin{array}{l}\text { Heat } \\
\text { Capacity, } \\
\text { Gcal/h }\end{array}$} & \multirow{2}{*}{$\begin{array}{c}\text { Coal Consumption } \\
\text { in 2020, Thousand } \\
\text { Tons of Oil } \\
\text { Equivalent }\end{array}$} & \multirow{2}{*}{$\begin{array}{c}\text { Sulfur } \\
\text { Content, \% }\end{array}$} & \multirow{2}{*}{$\begin{array}{c}\text { Ash } \\
\text { Content, \% }\end{array}$} & \multicolumn{4}{|c|}{$\begin{array}{l}\text { Approved ELV for } 2020 \text { per } \\
\text { Unit of Coal Consumption, } \\
\text { kg/ton of Oil Equivalent }\end{array}$} & \multicolumn{2}{|c|}{$\begin{array}{l}\text { Period of Validity of } \\
\text { ELV, Years }\end{array}$} & \multicolumn{4}{|c|}{ Emission Limit Value for 2020, tons } \\
\hline & & & & & & & $\mathrm{NO}_{2}$ & $\mathrm{SO}_{2}$ & $\mathrm{CO}$ & Dust & $\begin{array}{l}\text { Currently } \\
\text { Valid }\end{array}$ & $\begin{array}{l}\text { Previous } \\
\text { Period }\end{array}$ & $\mathrm{NO}_{2}$ & $\mathrm{SO}_{2}$ & $\mathrm{CO}$ & Dust \\
\hline 1 & Ust-Kamenogorsk CHP & 373 & 860 & 974 & 0.4 & 22 & 6.6 & 13.6 & 0.3 & 4.5 & 2019-2023 & 2018-2022 & 4470 & 9278 & 185 & 3077 \\
\hline 2 & Sogrinsk CHP & 75 & 232 & 230 & 0.4 & 17 & 5.7 & 14.1 & 0.1 & 3.1 & $2016-2020$ & 2014-2017 & 923 & 2273 & 14.5 & 495 \\
\hline 3 & Pavlodar CHP-1 & 350 & 1170 & 2057 & & & 6 & 19.3 & 1.4 & 8.3 & $2018-2027$ & $2017-2019$ & 8644 & 27,817 & 1951 & 12,017 \\
\hline 4 & Pavlodar CHP-2 & 110 & 332 & 400 & & & 6.4 & 19.8 & 0.8 & 4.8 & 2019-2028 & 2015-2019 & 1800 & 5532 & 223 & 1339 \\
\hline 5 & Pavlodar CHP-3 & 505 & 808 & 1657 & & & 6.5 & 18.2 & 1 & 5.3 & 2019-2028 & 2015-2019 & 7515 & 21,127 & 1112 & 6133 \\
\hline 7 & Ekibastuz GRES-1 & 4000 & - & 7886 & & & 9.5 & 34.5 & 1 & 5.7 & 2018-2022 & 2017-2021 & 52,642 & 190,565 & 5579 & 31,464 \\
\hline 8 & Ekibastuz GRES-2 & 1000 & 450 & 2509 & & & 8.3 & 34.7 & 0.4 & 6.4 & 2019-2023 & 2016-2020 & 14,575 & 60,958 & 615 & 11,296 \\
\hline 9 & Karaganda CHP-1 & 32 & 460 & 229 & 0.7 & 42 & 3.8 & 32.8 & 1.1 & 5.8 & $2017-2026$ & 2014-2016 & 602 & 5248 & 176 & 929 \\
\hline 10 & Karaganda CHP-3 & 670 & 1174 & 2160 & 0.7 & 42 & 7 & 13.1 & 0.4 & 4.2 & $2018-2022$ & 2015-2017 & 10,594 & 19,749 & 558 & 6304 \\
\hline 11 & Temirtau CHP & 632 & - & 3424 & 0.8 & 40 & 5.3 & 11.4 & 0.6 & 6.8 & $2017-2021$ & $2014-2016$ & 12,628 & 27,246 & 1420 & 16,381 \\
\hline 12 & Balkhash CHP & 200 & 417 & 607 & & & 5.5 & 29.7 & 1.3 & 8.4 & 2018-2022 & 2014-2018 & 2353 & 12,631 & 553 & 3571 \\
\hline 13 & Zhezkazgan CHP & 252 & 564 & 814 & 0.6 & & 9.8 & 27.1 & 1.8 & 5.2 & $2017-2020$ & 2015-2019 & 5613 & 15,425 & 1015 & 2968 \\
\hline 14 & Nur-Sultan CHP-1 & 22 & 862 & 217 & & 42 & 7.8 & 23.8 & 0.8 & 6.8 & 2020 & 2018-2019 & 1178 & 3608 & 126 & 1024 \\
\hline 15 & Nur-Sultan CHP-2 & 480 & 1918 & 2211 & & 44 & 8 & 23.8 & 1.6 & 4.7 & $2017-2020$ & 2017 & 12,431 & 36,880 & 2452 & 7256 \\
\hline 16 & Almaty CHP-1 & 145 & 1203 & 84 & 0.6 & 26 & & & & & $2016-2025$ & 2015-2019 & 1194 & 1209 & 235 & 270 \\
\hline 17 & Almaty CHP-2 & 510 & 1176 & 1612 & 0.7 & 42 & 7 & 20.6 & 1.6 & 7.8 & 2015-2024 & 2014-2018 & 7856 & 23,238 & 1752 & 8779 \\
\hline 19 & Petropavlovsk CHP & 581 & & 1829 & & 41 & 4.4 & 23.4 & 3.4 & 4.8 & $2016-2025$ & $\begin{array}{c}2015 \text { (no } \\
\text { exact date) }\end{array}$ & 5627 & 29,929 & 4347 & 6128 \\
\hline 20 & Rudnyi CHP & 267 & 134 & 1063 & & 43 & 5.3 & 11.3 & 10.5 & 24.1 & 2019-2026 & $2018-2026$ & 3950 & 8414 & 7843 & 17,921 \\
\hline \multirow[t]{3}{*}{21} & Ridder CHP & 59 & 247.3 & 214 & 0.4 & 13 & 6.1 & 9 & 0.1 & 5.3 & 2015-2024 & 2011-2015 & 919 & 1353 & 17 & 799 \\
\hline & Total & 12,886 & 12,537 & 36,758 & & & & & & & & & 188,582 & 622,745 & 37,787 & 202,871 \\
\hline & Average & & & & 0.6 & 35 & 6.7 & 21.4 & 1.5 & 7.3 & & & & & & \\
\hline
\end{tabular}


Table A2. Monthly average temperature and duration of the heating season by selected cities (Source: adapted from State standards in the field of architecture, urban planning and construction, 2017 https://igis.kz/images/snip/stroitelnyenormativy/sp-rk-2.04-01-2017-stroitelnaya-klimatologiya.pdf (accessed on 20 February 2021)).

\begin{tabular}{|c|c|c|c|c|c|c|c|c|c|c|c|c|c|c|c|c|}
\hline \multirow{2}{*}{ City } & \multicolumn{13}{|c|}{ Average Temperature, ${ }^{\circ} \mathrm{C}$} & \multicolumn{3}{|c|}{ Heating Season } \\
\hline & Jan & Feb & Mar & Apr & May & Jun & Jul & Aug & Sep & Oct & Nov & Dec & Mean & Start & End & Days \\
\hline Nur-Sultan & -15.1 & -14.8 & -7.7 & 5.4 & 13.8 & 19.3 & 20.7 & 18.3 & 12.4 & 4.1 & -5.5 & -12.1 & 3.2 & 29.09 & 26.04 & 211 \\
\hline Almaty & -5.3 & -3.6 & 2.9 & 11.5 & 16.5 & 21.5 & 23.8 & 22.7 & 17.5 & 9.9 & 2.6 & -2.9 & 9.8 & 22.10 & 03.04 & 165 \\
\hline Ust-Kamenogorsk & -15.8 & -14.6 & -7.6 & 5.6 & 13.7 & 18.6 & 20.2 & 18.2 & 12.2 & 5 & -5 & -12.4 & 3.2 & 04.10 & 25.04 & 205 \\
\hline Semei & -14.9 & -13.8 & -6.6 & 6.6 & 14.5 & 20.1 & 21.6 & 19.2 & 12.7 & 5 & -4.3 & -11.5 & 4.1 & 04.10 & 22.04 & 202 \\
\hline Temirtau & -13.6 & -13.2 & -6.6 & 5.8 & 13.3 & 18.9 & 20.4 & 18.3 & 12.3 & 4.1 & -4.8 & -11 & 3.7 & 30.09 & 25.04 & 209 \\
\hline Karaganda & -13.6 & -13.2 & -6.6 & 5.8 & 13.3 & 18.9 & 20.4 & 18.3 & 12.3 & 4.1 & -4.8 & -11 & 3.7 & 30.09 & 25.04 & 209 \\
\hline Balkhash & -13.9 & -12.7 & -4.4 & 8.2 & 16.3 & 22.2 & 24.2 & 22.1 & 15.5 & 6.9 & -1.9 & -9.7 & 6.1 & 11.10 & 16.04 & 189 \\
\hline Zhezkazgan & -13.8 & -13.2 & -5 & 8.7 & 16.2 & 22.4 & 24.4 & 22 & 15 & 5.9 & -3 & -10.2 & 5.8 & 05.10 & 16.04 & 195 \\
\hline Pavlodar & -16.6 & -15.5 & -7.6 & 5.7 & 13.8 & 19.8 & 21.4 & 18.6 & 12.3 & 4 & -6 & -13 & 3.1 & 02.10 & 25.04 & 207 \\
\hline Ekibastuz & -14.8 & -14.2 & -6.6 & 6.1 & 14 & 20 & 21.4 & 18.9 & 12.7 & 4.5 & -5.1 & -11.5 & 3.9 & 02.10 & 25.04 & 207 \\
\hline Aksu & -14.8 & -14.2 & -6.6 & 6.1 & 14 & 20 & 21.4 & 18.9 & 12.7 & 4.5 & -5.1 & -11.5 & 3.9 & 02.10 & 25.04 & 207 \\
\hline Aktobe & -13.3 & -12.9 & -5.7 & 7 & 15.2 & 20.7 & 22.8 & 20.5 & 14 & 5.2 & -3.3 & -9.6 & 5.1 & 04.10 & 20.04 & 200 \\
\hline Rudnyi & -15.5 & -14.9 & -7.5 & 5.5 & 14 & 19.6 & 20.8 & 18.4 & 12.5 & 4.3 & -5.6 & -12.4 & 3.3 & 01.10 & 23.04 & 206 \\
\hline
\end{tabular}

Table A3. Monthly average relative humidity by selected cities (Source: adapted from State standards in the field of architecture, urban planning and construction, 2017 https: / igis.kz/images/snip/stroitelnye-normativy/sp-rk-2.04-01-2017-stroitelnaya-klimatologiya. pdf (accessed on 20 February 2021)).

\begin{tabular}{|c|c|c|c|c|c|c|c|c|c|c|c|c|c|c|c|c|}
\hline \multirow{2}{*}{ City } & \multicolumn{16}{|c|}{ Relative Humidity, \% } \\
\hline & Jan & Feb & Mar & Apr & May & Jun & Jul & Aug & Sep & Oct & Nov & Dec & Mean & Winter & Summer & $\%$ \\
\hline Nur-Sultan & 78 & 77 & 79 & 64 & 54 & 53 & 59 & 57 & 58 & 68 & 80 & 79 & 67 & 78 & 56 & 28 \\
\hline Almaty & 78 & 76 & 71 & 59 & 57 & 49 & 47 & 45 & 49 & 63 & 73 & 79 & 62 & 78 & 47 & 40 \\
\hline Ust-Kamenogorsk & 76 & 75 & 77 & 64 & 57 & 62 & 67 & 64 & 63 & 69 & 77 & 77 & 69 & 76 & 64 & 16 \\
\hline Semei & 75 & 75 & 76 & 59 & 53 & 53 & 60 & 59 & 60 & 67 & 74 & 75 & 66 & 75 & 57 & 24 \\
\hline Temirtau & 79 & 78 & 78 & 61 & 54 & 50 & 55 & 52 & 53 & 65 & 77 & 78 & 65 & 78 & 52 & 33 \\
\hline Karaganda & 79 & 78 & 78 & 61 & 54 & 50 & 55 & 52 & 53 & 65 & 77 & 78 & 65 & 78 & 52 & 33 \\
\hline Balkhash & 79 & 78 & 75 & 56 & 51 & 46 & 49 & 47 & 47 & 60 & 74 & 79 & 62 & 79 & 47 & 41 \\
\hline Zhezkazgan & 78 & 77 & 75 & 57 & 48 & 40 & 42 & 40 & 44 & 60 & 76 & 79 & 60 & 78 & 41 & 47 \\
\hline Pavlodar & 79 & 79 & 80 & 62 & 54 & 55 & 60 & 61 & 62 & 71 & 80 & 80 & 69 & 79 & 59 & 25 \\
\hline Ekibastuz & 78 & 78 & 77 & 60 & 52 & 51 & 57 & 57 & 57 & 66 & 77 & 77 & 66 & 78 & 55 & 29 \\
\hline Aksu & 78 & 78 & 77 & 60 & 52 & 51 & 57 & 57 & 57 & 66 & 77 & 77 & 66 & 78 & 55 & 29 \\
\hline Aktobe & 81 & 79 & 79 & 66 & 57 & 54 & 55 & 54 & 58 & 69 & 80 & 82 & 68 & 81 & 54 & 33 \\
\hline Rudnyi & 83 & 82 & 82 & 68 & 58 & 57 & 64 & 64 & 64 & 72 & 82 & 83 & 72 & 83 & 62 & 25 \\
\hline
\end{tabular}

\section{References}

1. Climate Change 2014: Mitigation of Climate Change: Working Group III Contribution to the Fifth Assessment Report of the Intergovernmental Panel on Climate Change; Cambridge University Press: New York, NY, USA, 2014; ISBN 978-1-107-05821-7.

2. Geng, Y.; Wei, Y.-M.; Fischedick, M.; Chiu, A.; Chen, B.; Yan, J. Recent Trend of Industrial Emissions in Developing Countries. Appl. Energy 2016, 166, 187-190. [CrossRef]

3. Russell, A.; Ghalaieny, M.; Gazdiyeva, B.; Zhumabayeva, S.; Kurmanbayeva, A.; Akhmetov, K.K.; Mukanov, Y.; McCann, M.; Ali, M.; Tucker, A.; et al. A Spatial Survey of Environmental Indicators for Kazakhstan: An Examination of Current Conditions and Future Needs. Int. J. Environ. Res. 2018, 12, 735-748. [CrossRef]

4. World Bank $\mathrm{CO}_{2}$ Emissions (Kg per PPP \$ of GDP). Available online: https://data.worldbank.org/indicator/EN.ATM.CO2E.PP. GD (accessed on 17 January 2021).

5. Zonakz Almost $67 \%$ of All Emissions in Kazakhstan Come from the Electric Power Industry and the Mining and Metallurgical Sector. Available online: https:/ / zonakz.net/2019/12/24/pochti-67-vsex-vybrosov-v-rk-prixoditsya-na-elektroenergetiku-igorno-metallurgicheskij-sektor/ (accessed on 17 January 2021).

6. Government of the Republic of Kazakhstan. Environmental Code; 2007. Available online: http://adilet.zan.kz/rus/docs/K07000 0212_\#z1815 (accessed on 17 January 2021).

7. UNECE. Environmental Performance Reviews. Uzbekistan. Third Review. 2020. ISBN 978-92-1-117240-9. Available online: https: / / unece.org/environment-policy/publications/3rd-environmental-performance-review-uzbekistan (accessed on 17 January 2021). 
8. Abakanov, E. New Environmental Code of Kazakhstan: Expectations and Prospects. Available online: https://cabar.asia/ru/ novyj-ekologicheskij-kodeks-kazahstana-ozhidaniya-i-perspektivy (accessed on 17 January 2021).

9. Committee of Statistics of the Ministry of National Economy of the Republic of Kazakhstan. Environmental Protection and Sustainable Development of Kazakhstan. 2009-2013; 2014. Available online: https://stat.gov.kz/edition/publication/collection (accessed on 17 January 2021).

10. Committee of Statistics of the Ministry of National Economy of the Republic of Kazakhstan. Environmental Protection and Sustainable Development of Kazakhstan. 2014-2018; 2019. Available online: https://stat.gov.kz/edition/publication/collection (accessed on 17 January 2021).

11. IQAir World's Most Polluted Countries in 2019-PM2.5 Ranking I AirVisual. Available online: https://www.airvisual.com/ world-most-polluted-countries (accessed on 17 January 2021).

12. Ormanova, G.; Karaca, F.; Kononova, N. Analysis of the Impacts of Atmospheric Circulation Patterns on the Regional Air Quality over the Geographical Center of the Eurasian Continent. Atmos. Res. 2020, 237, 104858. [CrossRef]

13. World Bank Towards Cleaner Industry and Improved Air Quality Monitoring in Kazakhstan. 2013. Available online: https:// openknowledge.worldbank.org/handle/10986/17849 (accessed on 20 February 2021).

14. Nugmanova, D.; Feshchenko, Y.; Iashyna, L.; Gyrina, O.; Malynovska, K.; Mammadbayov, E.; Akhundova, I.; Nurkina, N.; Tariq, L.; Makarova, J.; et al. The Prevalence, Burden and Risk Factors Associated with Chronic Obstructive Pulmonary Disease in Commonwealth of Independent States (Ukraine, Kazakhstan and Azerbaijan): Results of the CORE Study. BMC Pulm. Med. 2018, 18, 26. [CrossRef] [PubMed]

15. Nugmanova, D.; Sokolova, L.; Feshchenko, Y.; Iashyna, L.; Gyrina, O.; Malynovska, K.; Mustafayev, I.; Aliyeva, G.; Makarova, J.; Vasylyev, A.; et al. The Prevalence, Burden and Risk Factors Associated with Bronchial Asthma in Commonwealth of Independent States Countries (Ukraine, Kazakhstan and Azerbaijan): Results of the CORE Study. BMC Pulm. Med. 2018, 18, 110. [CrossRef]

16. United States Environmental Protection Agency. Air Pollutant Emissions Trends Data. Available online: https://www.epa.gov/ air-emissions-inventories / air-pollutant-emissions-trends-data (accessed on 17 January 2021).

17. European Environment Agency Sulphur Dioxide $\left(\mathrm{SO}_{2}\right)$ Emissions-European Environment Agency. Available online: https: / / www.eea.europa.eu/data-and-maps/indicators/eea-32-sulphur-dioxide-so2-emissions-1 (accessed on 17 January 2021).

18. Wang, Z.; Zheng, F.; Zhang, W.; Wang, S. Analysis of $\mathrm{SO}_{2}$ Pollution Changes of Beijing-Tianjin-Hebei Region over China Based on OMI Observations from 2006 to 2017. Adv. Meteorol. 2018, 2018, 8746068. [CrossRef]

19. Zhao, P.; Tuygun, G.T.; Li, B.; Liu, J.; Yuan, L.; Luo, Y.; Xiao, H.; Zhou, Y. The Effect of Environmental Regulations on Air Quality: A Long-Term Trend Analysis of $\mathrm{SO}_{2}$ and $\mathrm{NO}_{2}$ in the Largest Urban Agglomeration in Southwest China. Atmos. Pollut. Res. 2019, 10, 2030-2039. [CrossRef]

20. Lin, W.; Xu, X.; Ma, Z.; Zhao, H.; Liu, X.; Wang, Y. Characteristics and Recent Trends of Sulfur Dioxide at Urban, Rural, and Background Sites in North China: Effectiveness of Control Measures. J. Environ. Sci. 2012, 24, 34-49. [CrossRef]

21. Guerreiro, C.B.B.; Foltescu, V.; de Leeuw, F. Air Quality Status and Trends in Europe. Atmos. Environ. 2014, 98, 376-384. [CrossRef]

22. Conti, M.E.; Ciasullo, R.; Tudino, M.B.; Matta, E.J. The Industrial Emissions Trend and the Problem of the Implementation of the Industrial Emissions Directive (IED). Air Qual. Atmos. Health 2015, 8, 151-161. [CrossRef]

23. Tang, L.; Qu, J.; Mi, Z.; Bo, X.; Chang, X.; Anadon, L.D.; Wang, S.; Xue, X.; Li, S.; Wang, X.; et al. Substantial Emission Reductions from Chinese Power Plants after the Introduction of Ultra-Low Emissions Standards. Nat. Energy 2019, 4, 929-938. [CrossRef]

24. Newell, J.P.; Henry, L.A. The State of Environmental Protection in the Russian Federation: A Review of the Post-Soviet Era. Eurasian Geogr. Econ. 2016, 57, 779-801. [CrossRef]

25. Cherp, A. Environmental Assessment in Countries in Transition: Evolution in a Changing Context. J. Environ. Manag. 2001, 62, 357-374. [CrossRef]

26. Carlsen, L.; Bruggemann, R.; Kenessov, B. Use of Partial Order in Environmental Pollution Studies Demonstrated by Urban BTEX Air Pollution in 20 Major Cities Worldwide. Sci. Total Environ. 2018, 610-611, 234-243. [CrossRef] [PubMed]

27. Kerimray, A.; Baimatova, N.; Ibragimova, O.P.; Bukenov, B.; Kenessov, B.; Plotitsyn, P.; Karaca, F. Assessing Air Quality Changes in Large Cities during COVID-19 Lockdowns: The Impacts of Traffic-Free Urban Conditions in Almaty, Kazakhstan. Sci. Total Environ. 2020, 730, 139179. [CrossRef]

28. Kerimray, A.; Bakdolotov, A.; Sarbassov, Y.; Inglezakis, V.; Poulopoulos, S. Air Pollution in Astana: Analysis of Recent Trends and Air Quality Monitoring System. Mater. Today Proc. 2018, 5, 22749-22758. [CrossRef]

29. Darynova, Z.; Amouei Torkmahalleh, M.; Abdrakhmanov, T.; Sabyrzhan, S.; Sagynov, S.; Hopke, P.K.; Kushta, J. SO 2 and HCHO over the Major Cities of Kazakhstan from 2005 to 2016: Influence of Political, Economic and Industrial Changes. Sci. Rep. 2020, 10, 12635. [CrossRef]

30. Kenessary, D.; Kenessary, A.; Adilgireiuly, Z.; Akzholova, N.; Erzhanova, A.; Dosmukhametov, A.; Syzdykov, D.; Masoud, A.-R.; Saliev, T. Air Pollution in Kazakhstan and Its Health Risk Assessment. Ann. Glob. Health 2019, 85, 133. [CrossRef] [PubMed]

31. Semenova, Y.; Zhunussov, Y.; Pivina, L.; Abisheva, A.; Tinkov, A.; Belikhina, T.; Skalny, A.; Zhanaspayev, M.; Bulegenov, T.; Glushkova, N.; et al. Trace Element Biomonitoring in Hair and Blood of Occupationally Unexposed Population Residing in Polluted Areas of East Kazakhstan and Pavlodar Regions. J. Trace Elem. Med. Biol. 2019, 56, 31-37. [CrossRef]

32. Kerimray, A.; Assanov, D.; Kenessov, B.; Karaca, F. Trends and Health Impacts of Major Urban Air Pollutants in Kazakhstan. J. Air Waste Manag. Assoc. 2020, 70, 1148-1164. [CrossRef] 
33. Kazhydromet. Information Bulletins on the State of the Environment of the Republic of Kazakhstan. 2020. Available online: https://www. kazhydromet.kz/en/ecology/informacionnye-byulleteni-o-sostoyanii-okruzhayuschey-sredy-respubliki-kazahstan (accessed on 17 January 2021).

34. Order of the Minister of National Economy of the Republic of Kazakhstan. Hygienic Standards for Atmospheric Air in Urban and Rural Settlements. 2015. Available online: http:/ / adilet.zan.kz/rus/docs/V1500011036 (accessed on 17 January 2021).

35. WHO Ambient (Outdoor) Air Pollution. Available online: https://www.who.int/news-room/fact-sheets/detail/ambient(outdoor)-air-quality-and-health (accessed on 17 January 2021).

36. Issanova, G.; Abuduwaili, J. Aeolian Processes in the Arid Territories of Central Asia and Kazakhstan; Environmental Science and Engineering; Springer: Singapore, 2017; ISBN 978-981-10-3189-2.

37. Nobakht, M.; Shahgedanova, M.; White, K. New Inventory of Dust Emission Sources in Central Asia and Northwestern China Derived from MODIS Imagery Using Dust Enhancement Technique. Geophys. Res. Atmos. 2021, e2020JD033382. [CrossRef]

38. Zhang, X.-X.; Claiborn, C.; Lei, J.-Q.; Vaughan, J.; Wu, S.-X.; Li, S.-Y.; Liu, L.-Y.; Wang, Z.-F.; Wang, Y.-D.; Huang, S.-Y.; et al. Aeolian Dust in Central Asia: Spatial Distribution and Temporal Variability. Atmos. Environ. 2020, 238, 117734. [CrossRef]

39. Committee of Statistics of the Ministry of National Economy of the Republic of Kazakhstan. Transport in the Republic of Kazakhstan. 2015-2019; 2020. Available online: https:/ / stat.gov.kz/edition/publication/collection (accessed on 17 January 2021).

40. Clean Household Energy Consumption in Kazakhstan: A Roadmap—Analysis. Available online: https://www.iea.org/reports/ clean-household-energy-consumption-in-kazakhstan-a-roadmap (accessed on 10 February 2021). 